Makale Geliș| Received: 06.02.2020.

Makale Kabul| Accepted: 02.03.2020

DOI: 10.18795/gumusmaviatlas.685650

Mavi Atlas, 8(1)2020: 81 - 106

Araştırma Makalesi|Research Article

Fatma ALTUN

Dr. Öğr. Üyesi|Assist. Prof.Dr.

Trabzon Üniversitesi, Fatih Eğitim Fakültesi, Eğitim Bilimleri Bölümü, Trabzon-TÜRKIYYE

Trabzon University, Fatih Faculty of Education, Department of Educational Sciences, Trabzon-TURKEY

ORCID: 0000-0001-8523-7768

faltun@trabzon.edu.tr

Hikmet YAZICI

Prof. Dr.|Prof. Dr.

Trabzon Üniversitesi, Fatih Eğitim Fakültesi, Eğitim Bilimleri Bölümü, Trabzon-TÜRKIYYE

Trabzon University, Fatih Faculty of Education, Department of Educational Sciences, Trabzon-TURKEY

ORCID: 0000-0002-0250-1453

hyazici@trabzon.edu.tr

\title{
Rehber Öğretmenlerin Üstün Yetenekli Öğrencilere Sunulan Psikolojik Danışma ve Rehberlik Hizmetleri ile İlgili Görüşleri ${ }^{1}$
}

Öz

Bu çalışmada üstün yetenekli öğrencilerin eğitim gördükleri okul ve Bilim Sanat Merkezlerinde (BİLSEM) görev yapmakta olan rehber öğretmenlerin, üstün yetenekli öğrencilere dönük psikolojik danışma ve Rehberlik (PDR) hizmetleri ile ilgili görüşlerinin incelenmesi amaçlanmıştır. Durum çalışması olarak tasarlanan bu araştırmada, yarı yapılandırılmış mülakat tekniği kullanılmıştır. Araştırmanın katılımcılarının belirlenmesinde, amaçlı örnekleme yönteminden yararlanılmıştır. Buna göre araştırma grubunda farklı kurum türlerinde çalışan 8 rehber öğretmen $(K=6$, $\mathrm{E}=2$ ) yer almaktadır. Mülakatlarla elde edilen veriler, betimsel analiz yöntemi ile analiz edilmiştir. Bu süreçte veriler, araştırma sorularının ortaya koyduğu temalara göre düzenlenmiştir. Araştırma soruları çerçevesinde görüşmelerden elde edilen veriler tanımlanmış ve gerekli yerlerde doğrudan alıntılarla desteklenmiştir. Araştırma sonucunda ortaya çıkan temalardan bazıları; "Rehber Öğretmenlerin Üstün Yeteneklilerle ilgili Eğitim Geçmişleri”, "Üstün Yetenekli Öğrencilerin PDR İhtiyaçları”, “Üstün Yetenekli Öğrencilerin PDR İhtiyaçlarına Dönük Yapılan Çalışmalar”, “Okul/ BİLSEM Rehberlik Programının Üstün Yetenekli Öğrencilerin İhtiyaçlarını Karşılama Durumu”, "Rehber Öğretmenlerin Üstün Yetenekliler için Kullandıkları Yöntemlerden Başarılı veya Başarısız/ Kullanışsız Buldukları Aktivite ve Roller", "Üstün Yeteneklilerle Çalışan Rehber Öğretmenlerin Eğitimlerine ve Hazırlıklarına İlişkin Görüşler”, "Üstün Yetenekliler Programının ve Okuldaki Uygulamaların Üstün Yetenekli Öğrencilerin Eğitim ve Kariyer Olanaklarına Özel Olarak Hitap Etme Durumu”, "Bölgedeki Üstün Yetenekli Öğrencilerin Eğitimiyle ilgili En Önemli Konu/ Sorunlara İlișkin Rehber Öğretmenlerin Görüșleri”, ve "Üstün Yetenekli Öğrencilere Özgü Bir Rehberlik Programının Geliştirilmesine Dönük Öneriler” başlıkları altında toplanmış ve sonuçlar tartışılmıştır.

Anahtar Kelimeler: Üstün/Özel Yetenekli Öğrenci, Rehber Öğretmen, Psikolojik Danışma ve Rehberlik.

\section{School Counselors' Views on Psychological Counseling and Guidance Services Provided to Gifted Students ${ }^{2}$}

\section{Abstract}

The aim of this study was to examine the perceptions and opinions of the school counsellors, working in the schools and Science and Arts Centers (SAC) where gifted students are educated, about counseling and guidance services for gifted students. In this study, which was designed as a case study, semi-structured interview technique was utilized. Purposeful sampling method was used to select the sample and eight school counselors, who work in different types of institutions, participated in the study. The data obtained through the interviews were analysed by descriptive analysis

\footnotetext{
${ }^{1}$ Bu çalışma ilk yazara ait doktora tezinin bir bölümünden üretilmiş ve bir kısmı 24 Kasım Baş Öğretmen Eğitim ve Yenilikçi Bilimler Kongresinde sunulmuştur. Doktora tezi kapsamında yürütülen bu çalışmanın etik kurul izni alınmıştır.

${ }^{2}$ This paper was produced from a section of the first author's doctoral dissertation and part of this study was presented at International Congress on 24 November Chief Teacher; Education and Innovative Sciences.
} 
method. The data were analysed, coded and themes were generated. The data obtained from the interviews were identified within the framework of the research questions and direct quotations were provided where necessary. Some of the themes that emerged out of the study are as following "School Counselors' Training Backgrounds for Gifted Students", "Counseling Needs of Gifted Students", "Practices on Counseling Needs of Gifted Students", "The extent of School/SAC Counseling and Guidance Program to Meet the Needs of Gifted Students", "Activities and Roles that Counselors Find Successful or Unsuccessful/Useless from the Methods They Use for Gifted Students", "Opinions on the Training and Preparation of Counselors Working with Gifted Students", "The State of Gifted Program and Practices in the School to Address the Educational and Career Development of Gifted Students", "Opinions of the School Counselor on the Most Important Issues/Issues Concerning the Education of Gifted Students in the Region", "Suggestions for Developing a Specific Guidance Program for Gifted Students".

Keywords: Gifted Student, Talented Student, School Counselor, Psychological Counselling and Guidance.

\section{Giriş}

Zekâ, yaratıcılık, sanat, liderlik kapasitesi ve özel akademik alanlardan birinde veya birkaçında, yaşıtlarına oranla yüksek düzeyde performans gösteren bireyler özel/üstün yetenekli olarak tanımlanmaktadır (Colangelo ve Davis, 2003:5). Bunların dışında üstün yeteneklilik; merak, motivasyon, analitik ve üretken düşünme becerisi, bağımsızlık ve sezgisellik gibi özelliklerle de ilişkilendirilmektedir (Strickland, 2001:281-282). Özel/üstün yetenekli öğrencilerin akranlarından farklılaştıkları alanlar, sadece zihinsel ve özel akademik yetenekleri değildir. Bu öğrenciler, bazı gelişimsel ve psikolojik özellikleri bakımından da üstün yetenekli olmayan akranlarından ayrilırlar (Milgram, 1991a; Moon, 2007; Silverman, 1993a). Örneğin, psiko-motor, duyusal, imgesel, duygusal ve entelektüel alanlarda aşırı duyarlılıkları (Piechowski, 2009:178-180), üstün yetenekli öğrencilerin karakteristik özelliklerindendir. Bunların yanı sıra; eş zamanlı olmayan gelişim (Silverman, 1993:4), mükemmeliyetçilik (Parker ve Adkins, 1995) ve 1raksak düşünme (Johnsen, 2004:1-24) gibi üstün yetenekli öğrencileri normal gelişim gösteren akranlarından ayıran bazı özellikler, onların faydalı ürün ya da yüksek performans göstermesine katkıda bulunabilir. Fakat bunun için farklılaştırılmış eğitim hizmetlerine gereksinim duydukları, aksi takdirde bu özelliklerin öğrenciler için avantaj sağlamaktan çok dezavantaj oluşturabileceği unutulmamalıdır.

Üstün/özel yetenekli öğrenciler, akranlarından farklılaşan özellikleri nedeniyle özel eğitime gereksinimli gruplar arasında yer almaktadır (Milli Eğitim Bakanlığ1, 2018). Literatürde üstün/özel yeteneklilere sunulan eğitim hizmetlerinin programlanmasını ve etkililiğini ele alan pek çok çalışma mevcuttur (örn. Çağlar 2004; Özdemir, 2018; Schiever ve Maker, 2003; Van Tassel-Baska, 2019). Fakat çağdaş eğitim sisteminde bireyin yalnızca akademik alanda değil tüm yönleri ile gelişiminin hedef alındığ yeteneklilerin sadece akademik gelişimlerine odaklanıldığı ve sosyal-duygusal boyutlarının ihmal edildiği görülmektedir. Bu ihmalin temelinde üstün yeteneklilerin gelişmiş zihinsel özellikleri sayesinde psikolojik olarak daha sağlıklı oldukları yönündeki inanış yer almaktadır (Hansen, 2009; Kerr, 1991; Neihart, 1999). Bu görüşe göre, üstün yetenekli çocuklar yalnızca akademik değil fiziksel, sosyal ve psikolojik yönlerden de yaşıtlarından daha üstündürler. Bu nedenle okullardaki psikolojik danışma ve rehberlik (PDR) hizmetlerine dahi gereksinim duymadıklarına inanılmıştır. Buna karşın Hollingworth (1942) gibi bazı araştırmacılar ve kurulan rehberlik merkezleri sayesinde üstün yeteneklilerin kendilerine özgü problem alanlarına sahip oldukları tespit edilmiştir. Yapılan araştırmalar, üstün yeteneklilerin psikolojik durumlarıyla ilgili ortaya atılan zıt kutuplardaki iki görüşün birleşimini desteklemektedir (Colangelo ve Assouline, 2000; Milgram, 1991b). Buna göre, üstün yeteneklilik patolojik bir durum olmadığı gibi bireyleri her tür psikolojik problemden koruyan bir kalkan da değildir. Üstün yetenekli bireyler normal yetenek düzeyindeki akranlarının yaşadığı sıradan gelişimsel süreçlerin yanı sıra üstün yeteneklilikle ilişkili olan bir takım zorlayıcı faktörlerle de karşılaşırlar. Gelişmiş yetenekleri ve akranlarından farklı özellikleri, karşılaştıkları bu sorunlarla başa çıkmada bazen kendilerine yardımcı olabilir. Fakat kimi zaman bu farklı özelliklerinin problemin asıl kaynağı olduğu da bilinmektedir (Webb, 1994). 
Üstün yetenekli öğrencilerin sorunlarının yalnızca onların farklı gelişimsel ve kişisel özellikleriyle sınırlı olduğu söylenemez. Aile ve arkadaş ilişkileri, uygun olmayan okul ortamları, üstün yeteneklilik etiketi, cinsiyet ve kültür gibi birçok dışsal faktör, üstün yeteneklilerin yaşadığ1 sorunlarla ilişkili olabilmektedir. Tüm faktörler sonucunda ortaya çıkan sorunların eğitim süreci içerisinde sunulan PDR hizmetleri ile ele alınması gerekir. Üstün yeteneklilerle çalışan rehber öğretmenlerin bu öğrencilerin karakteristik özellikleri hakkında bilgi sahibi olmaları ve PDR hizmetlerini bu özellikleri dikkate alarak düzenlemeleri gerektiği literatürde sıklıkla ifade edilmektedir (Colangelo ve Assouline, 2000; Moon, 2002a; Van Tassel-Baska, 1990).

Üstün yetenekli öğrencilerin eğitsel alanda PDR hizmetlerine ihtiyaç duydukları sorunlara; öğrenme bozuklukları veya dikkat eksikliği ve hiperaktivite bozukluğu (DEHB) (Moon, 2002b), beklenmedik başarısızlık (Seeley, 1993:263), okul terki (Renzulli ve Park, 2002) ve düşük motivasyon (Başlantı ve McCoach, 2006) örnek olarak verilebilir. Mesleki alanda yaşadıkları sorunlar ise; mesleğe karar verememe veya geç tercih yapma, tek bir alana yoğunlaşıp diğer meslek alanlarını tanıyamama, yaratıcılık gibi bazı özellikleri arka planda bırakma, sık sık iş veya alan değiştirme şeklinde gözlenebilir (Kerr, 1991; Kerr ve Sodano, 2003). Aşııı duyarlılık, mükemmeliyetçilik, sosyal izolasyon, depresyon ve intihar (Colangelo, 2003:373) ise üstün yeteneklilerin kişisel-sosyal rehberlik alanında yaşadıkları sorunların başlıcalarıdır. Sunulacak yardım hizmetlerinde; üstün yeteneklilerin özelliklerinin tanınması ve onlara özgü müdahale yaklaşımlarının belirlenmesi önemlidir. Bu anlamda Türkiye'de üstün yetenekli öğrencilerin bazı psikolojik özelliklerinin belirlenmesi (Altun ve Yazıc1, 2014; Koçak ve İçmenoğlu, 2012) ve PDR ihtiyaçlarının saptanmasına yönelik çalışmaların (Altun ve Yazıcı, 2018a; Bahtiyar ve Şahin, 2017) anlamlı katkıları olabilir. Fakat rehber öğretmenlerin eğitim geçmişlerinin (Yazıc1 ve Altun, 2016), üstün yeteneklilere dönük farklılaştırılmış programları geliştirme açısından yeterli olduğu söylenemez. Ayrıca üstün/özel yetenekli öğrencilerle yapılan bir çalışmanın (Altun ve Yazıcı, 2018b) sonucu da okul ve Bilim Sanat Merkezlerinde (BİLSEM) sunulan PDR hizmetlerin öğrencilerin ihtiyaçlarını karşılama konusunda yetersiz kaldığı alanlar olduğunu göstermektedir.

Üstün/özel yetenekli çocukların eğitimi, tüm dünyada olduğu gibi Türkiye’de de farklı boyutlarıla incelenmesi gereken bir konudur. PDR hizmetleri bu ana konunun bileşenlerinden biridir. Üstün yeteneklilerde PDR hizmetleri; sorunların tespit aşamasından müdahaleye kadar, bilimsel araştırma sürecinin her basamağında farklı yöntem ve tekniklerle incelenmesi gereken bir alandır. Bu çalışmada, özel yetenekli öğrencilerle çalışan rehber öğretmenlerin bu öğrencilere sunulan PDR hizmetleri hakkındaki görüşlerinin incelenmesi amaçlanmaktadır.

\section{Yöntem}

\section{Araştırmanın Deseni}

Araştırmada benimsenen yöntem durum çalışmasıdır (case study). Durum çalışması, nasıl ve niçin sorularını temel alan, araştırmacının kontrol edemediği bir olgu veya olayı derinliğine incelemesine olanak sağlayan bir araştırma yöntemidir (Yıldırım ve Şimşek, 2008:277). Durum çalışmasının araştırmacıya özel bir konu ya da durum üzerinde yoğunlaşma firsatı vermesi, avantajlı bir özellik olarak görülmektedir. Ayrıca araştırılan durumu açıklamaya ve değerlendirmeye olanak sağlaması bu yöntemin diğer güçlü özellikleridir (Gall, Gall ve Brog, 2003:440). Bununla birlikte uzun zaman alması, sonucunda okunması güç ve çok fazla doküman elde edilmesi gibi bazı konularda durum çalışmasının eleştirildiği görülmektedir (Yıldırım ve Şimşek, 2008:280). Bu araştırmadaki durum çalışması kapsamında yarı yapılandırılmış mülakat tekniğinden yararlanılmıştır. Yarı yapılandırılmış mülakat, araştırmacının bilgi almak istediği konularla ilgili olarak önceden hazırladığ1 yapılandırılmış soruların yanında katılımcıların cevaplarına dayalı olarak ek soruların sorulabildiği bir tekniktir (Gall, Gall ve Brog, 2003:240). 
ALTUN, Fatma ve Hikmet YAZICI (2020). “Rehber Öğretmenlerin Üstün Yetenekli Öğrencilere Sunulan Psikolojik Danışma ve Rehberlik Hizmetleri ile İlgili Görüşleri”, Ma vi Atlas, 8(1): 81 -106

\section{Araştırma Grubu}

Çalışmanın araştırma grubunda, görev yaptığı kurumda üstün yetenekli (ÜY) öğrencilerin öğrenim gördüğü 8 okul rehber öğretmeni yer almaktadır. Araştırma grubuna ait bazı tanımlayıc1 bilgiler Tablo 1'de özetlenmiştir. Buna göre, görüşmeye katılan rehber öğretmelerin 2'si erkek, 6's1 kadındır. Katılımcılar ilkokul, ortaokul, Fen ve Anadolu lisesi, özel okul, BiLSEM olmak üzere farklı kurum türlerinde çalışmaktadırlar. Kıdemleri 7 ile 25 yıl arasında değişen rehber öğretmenlerden üçü yüksek lisans mezunudur.

Tablo 1. Görüşme Yapılan Rehber Öğretmenlere İlişkin Bazı Tanımlayıcı Bilgiler

\begin{tabular}{|c|c|c|c|c|c|}
\hline Katılımc1 & Cinsiyet & Eğitim Düzeyi & Çalışılan Kurum Türü & Kidem & ÜY ile Çalışma \\
\hline R1 & Kadın & Yüksek Lisans & Ortaokul & $7 \mathrm{y} y 1$ & $5 \mathrm{y} 1 \mathrm{l}$ \\
\hline $\mathrm{R} 2$ & Erkek & Lisans & Fen Lisesi & $16 \mathrm{y} 1 \mathrm{l}$ & 2 y1l \\
\hline $\mathrm{R} 3$ & Kadın & Lisans & İlkokul & 14 y1l & $1 \mathrm{y} 1 \mathrm{l}$ \\
\hline $\mathrm{R} 4$ & Kadin & Yüksek Lisans & Anadolu Lisesi & 15 yil & $15 \mathrm{y} 1 \mathrm{l}($ aralıklı) \\
\hline R5 & Kadin & Lisans + Formasyon & Özel ilkokul+ortaokul & 9 y1l & 5 y1l \\
\hline R6 & Kadın & Lisans & Mesleki Ortaokul (İHO) & 25 y1l & 20 yil (aralıkli) \\
\hline R7 & Kadın & Lisans & BİLSEM & 20 y1l & 8 y1l \\
\hline $\mathrm{R} 8$ & Erkek & Yüksek Lisans & BİLSEM & $16 \mathrm{y} 1 \mathrm{l}$ & $10 \mathrm{y} 1 \mathrm{l}$ \\
\hline
\end{tabular}

\section{Araştırmada Kullanılan Veri Toplama Araçları}

\section{Demografik Bilgi Formu}

Araştırmaya katılan okul rehber öğretmenlerinin yaş, cinsiyet, çalıştıkları kurum türü, mesleki kıdem yılı ve eğitim düzeyleri gibi tanımlayıcı bilgileri elde etmek amacı ile araştırmacılar tarafindan oluşturulmuştur.

\section{Görüşme (Mülakat) Formu}

Üstün yeteneklilerin PDR ihtiyaçları ve rehber öğretmenlerin üstün yeteneklilerle ilgili yeterlik düzeylerini BİLSEM ve okul rehber öğretmenlerinin görüşlerine dayalı olarak belirlemek amacıyla, araştırmacılar tarafindan yarı yapılandırılmış mülakat (görüşme) formu hazırlanmıştır. İlgili literatür taranarak, araştırmanın amacı derinlemesine bilgi edinmeye olanak sağlayacak şekilde hazırlanan sorular, kapsam geçerliliği açısından alandaki bir uzmana incelettirilmiştir. Görüşme formu hazırlanırken, soruların anlaşılabilirlĭgi, mantıklı bir biçimde düzenlenmesi, odaklı (spesific) ve açık uçlu olması, yönlendirmeden ve çok boyutluluktan kaçınılması gibi ilkeler (Yıldırım ve Şimşek, 2008) dikkate alınmıştır. Örneklem grubunda yer almayan iki rehber öğretmene uygulanan görüşme formunda bazı soruların yerleri değiştirilmiş ve bir soru sonda soru olarak yeniden düzenlenmiştir. Böylece yarı yapılandırılmış görüşme formuna son şekli verilmiştir.

\section{Araştırmanın İşlem Yolu}

Araştırma için gereken etik kurul izni Karadeniz Teknik Üniversitesi Hukuk Müşavirliğinden alınmıştır (sayı no: 82554930/400-1578). Araştırmanın verilerinin toplanması amacıyla öncelikle belirlenen rehber öğretmenlerden randevu talep edilmiştir. Gönüllülük ilkesine göre hareket edilmiş ve görüşmeler hakkında gerekli açıklamalar kendilerine yapılmıştır. Araştırmacıların belirlediği rehber öğretmenlerin hepsinden katılımla ilgili olumlu cevap alınmıştır. Yarı yapılandırılmış görüşmeler, önceden belirlenen saatlerde, rehber öğretmenlerin okullardaki odalarında, ses kayıt cihazı eşliğinde gerçekleştirilmiştir. Sorular araştırmacılar tarafından rehber öğretmenlere yöneltilmiş, gerektiğinde sonda sorulara ve bazı alternatif sorulara yer verilmiştir. Verilerin elde edilmesi sürecinde katılımcıları etkilememeye ve yönlendirmemeye özen gösterilmiştir. Görüşmelerin toplam süresi 30 ile 60 dakika arasında değişiklik göstermektedir. 
Nicel araştırmalarda ölçüt olarak kullanılan geçerlik yerine, nitel araştırmalarda inanırlık kavramı tercih edilir. İnanırlık, bir araştırma deseninin araştırılanın doğru bir şekilde teşhis edilip, kapsamlı şekilde betimlendiği bir yolla araştırmanın gerçekleştirildiğini göstermektir (Robson, 1993). Bir araştırma deseninin kontrol mekanizması olarak tanımlanan inanırlık, sonuçların yorumlanmasında güvenin, araştırma bulgularının araștırmacıya, katılımcılara ve okuyuculara inandırıcı gelmesinin ve bulguların araştırmanın gerçek bir resmi olup olmadığının bir ölçütüdür (Miles ve Huberman, 1994). Bu çalışmanın nitel bölümünde inanırlı̆̆ sağlamak için çeşitli stratejiler kullanılmıştır (Lincoln ve Guba, 1985; Shenton, 2004). Bunlardan ilki katılımcı teyidinin sağlanmasıdır. Bu kapsamda, araştırmacılar, her sorudan sonra topladığı verileri katılımcılara özetleyerek bunların doğruluğunu, eklemek istedikleri herhangi bir şey olup olmadığını sormuştur. Katılımcılardan gelen düzeltmeler ele alındıktan sonra veriler analize hazır hale getirilmiştir. Araştırma konusu hakkında genel bilgiye sahip bir uzmanın, verilerin toplanması, analizi ve sonuçların yazımı ile ilgili geri bildirimlerde bulunması, bu araştırmada inanırlığın sağlanması için tercih edilen bir diğer yöntemdir. Ayrıca inanırlı̆̆ın artırılması için okuyucunun araştırılanı ve bağlamını anlamasına yardımcı olacak şekilde araştırılan olgu kapsamlı bir şekilde betimlenmeye çalışılmıştır. Bununla birlikte konu ile ilgili mevcut literatür incelenmiş ve sonuçların uyumluluğu kontrol edilmiştir.

Nicel araştırmalardaki güvenirlik ölçütü yerine nitel araştırmalarda tutarlılık dikkate alınır. Tutarlılık, araştırma sürecinin uygunluğu, zaman içerisinde hem araştırmacılar hem de kullanılan veri toplama teknikleri açısından gösterilen kararlılık olarak tanımlanır (Miles ve Huberman, 1994). Bir başka ifade ile tutarlılık, araştırma sürecinde izlenen yolların ve alınan kararların, diğer araştırmacılar tarafından ne düzeyde uygun ve mantıklı olarak değerlendirildiğidir (Denscombe, 2007). Bu çalışmada tutarlıllğın sağlanması için izlenen stratejilerden (Lincoln ve Guba, 1985; Shenton, 2004) biri araştırmanın pilot çalışmasının yapılmasıdır. Bunun yanı sıra okuyucuların baştan sona kadar izlenen yolları takip edebilecekleri şekilde, araştırma sürecinde nelerin nasıl yapıldığı açıkça belirtilmiştir. Araştırmanın tutarlılığının artırılması için araştırma soruları açı ve araştırma süreciyle uyumlu şekilde düzenlenmiştir.

\section{Araştırmada Kullanılan Veri Analiz Teknikleri}

Araştırmadaki yarı yapılandırılmış mülakatlarla elde edilen veriler, betimsel analiz yöntemi ile analiz edilmiştir. Bu süreçte veriler, araştırma sorularının ortaya koyduğu temalara göre düzenlenmiştir. Araştırma soruları çerçevesinde görüşmelerden elde edilen veriler tanımlanmış ve gerekli yerlerde doğrudan alıntılarla desteklenmiştir.

\section{Bulgular}

\section{Rehber Öğretmenlerin Üstün Yeteneklilerle İlgili Eğitim Geçmişleri}

Rehber öğretmenlerin üstün yetenekli öğrencilerle ilgili eğitim geçmişleri ile ilgili bulgular Tablo 2'de özetlenmiştir. Tabloda görüldüğü gibi öğretmenlerin çoğu üstün yeteneklilere dönük kapsamlı bir eğitim almamıştır. Katılımcıların çoğu üstün yeteneklilerin tanılanmasında kullanılan grup yetenek (Temel Kabiliyetler Testi [TKT], Temel Yetenek Testi [TYT]) veya bireysel zekâ (Wechsler Çocuklar için Zekâ Testi [WISC-R]) testleriyle ilgili hizmet içi eğitimler aldıklarını belirtmişlerdir. Fakat bu eğitimlerde yalnızca testin ve uygulanışının tanıtıldığı, üstün yeteneklilerin özellikleri ve ihtiyaçlarıyla ilgili bilgilere yer verilmediği vurgulanmıştır. Katılımcılardan R2 ve R7 bu konuyla ilgili görüşlerini şu şekilde ifade etmektedirler:

Orda testin nasıl uygulanacağı, ondan sonra da formatör gözetiminde bizler de birer sınıfa uygulama şeklinde iki uygulamamız vardı. Yoksa öyle şey yok, ayrıntılı bir bilgilendirme yoktu. (R3) 
WISC-R uzmaniyım, her sene tanilama yapiyordum buraya (BİLSEM) görevlendiriliyordum üstün yeteneklileri tanıllyordum ama üstün yeteneklilerin özelliklerini daha yakından tanıma daha iyi öğrenme buraya başladıktan sonra oldu. (R7)

Araştırmaya katılan rehber öğretmenlerin büyük bir bölümü, üstün yeteneklilerle ilgili konulara lisans düzeyinde aldıkları özel eğitim alanıyla ilgili bazı derslerin içeriğinde yer verildiğini ancak bunun yeterli olmadığını vurgulamışlardır. Katılımcıların çoğu ihtiyaç duyduklarında kendi çabalarıyla araştırarak birtakım bilgiler edindiklerini vurgulamışlardır. R1 ve R5 bu konudaki görüşlerini aşağıdaki gibi ifade etmektedirler:

Lisansta da yüksek lisansta da bu alanla ilgili özel bir dersim olmadı. Dersler içerisinde zaman zaman geçiyordu. Sanırım özel eğitim branşlı olan derslerde, küçük çaplı olmuştu diye hattrliyorum. (R1)

Ayrı bir eğitim almadım ama derslerimiz içerisinde aldığımız bilgiler oldu. Bir de gelen öğrencilerim oldukça da araştırmalarımla birlikte kendime bilgi sağladım. (R5)

Rehber öğretmenlerden yalnızca BİLSEM'de görev yapanların çalıştay ve seminer gibi etkinliklere katıldıkları görülmektedir. BİLSEM rehber öğretmenleri katıldıkları seminer ve çalıştaylar konusundaki yetersizlikleri ve bunların doğrudan PDR alanıyla ilgili olmayışını şu şekilde ifade etmektedirler:

Buraya seçilirken bir haftalık bir kursa gittim. Bir de geçen sene Rize'de üstün yeteneklilikle ilgili bir seminere gittim. Onun dışında başvuruda bulunduğum zamanlar oldu ama seçilme durumum olmadı. Bakanlık (MEB) çok fazla rehber öğretmenlere yönelik bir çalışma yapmadi. Yani daha ziyade Bakanlıktan kaynaklanan bir durum oldu. (R7)

Bu kuruma gelirken, seçilirken Bakanlığın bizi göndermiş olduğu hizmet içi eğitim sürecinden geçtik. Bunun dışında yine zaman zaman Bakanlığın düzenlemiş olduğu kongre ya da çalıştaylar oluyor. Onlara katıllyoruz. En son Zekâ Vakfinın düzenlemiş olduğu Ankara'daki kongre vardı oraya gittik, atölye çalışmalarına katıldık. Bu kongreye kendi imkânlarımızla gittik ama Bakanlığın düzenlemiş oldukları da var. Tam tarihini bilmiyorum ama önümüzdeki süreçte rehber öğretmenlere yönelik Bakanlığın bir eğitim çalıştayı olacak. Bu olursa ilk defa (rehber öğretmenlere yönelik hizmet içi eğitim) olacak. (R8)

Tablo 2. Rehber Öğretmenlerin Üstün Yeteneklilerle İlgili Eğitim Geçmişleri

\begin{tabular}{|c|c|c|c|c|c|c|c|c|}
\hline & R1 & $\mathrm{R} 2$ & R3 & $\mathrm{R} 4$ & R5 & R6 & R7 & $\mathrm{R} 8$ \\
\hline Lisansta özel eğitim dersi içerisinde bir bölüm & $\checkmark$ & $\checkmark$ & $\checkmark$ & & & & & $\checkmark$ \\
\hline Tanılamada kullanılan testlerle ilgili hizmet içi eğitim & $\checkmark$ & $\checkmark$ & $\checkmark$ & $\checkmark$ & & $\checkmark$ & $\checkmark$ & \\
\hline Kişisel araştırma ve okumalar & & & $\checkmark$ & $\checkmark$ & $\checkmark$ & & $\checkmark$ & $\checkmark$ \\
\hline BİLSEM'e giriş öncesi bir haftalık eğitim & & & & & & & $\checkmark$ & $\sqrt{ }$ \\
\hline Çalıștaylar ve seminerler & & & & & & & $\checkmark$ & $\checkmark$ \\
\hline
\end{tabular}

Üstün Yetenekli Öğrencilerin Temel İhtiyaçları ve Bunların Karşılanmasında

\section{Rehber Öğretmenlerin Rolü}

Tablo 3’te "Üstün yetenekli öğrencilerin temel ihtiyaçları olarak gördügünüz şeyler nelerdir ve okul rehberlik servisleri bunları nasıl karşılayabilir" sorusuna verilen cevapların özeti sunulmuştur. Anlaşılma ve farklılıklarının kabul edilmesi rehber öğretmenlerin çoğu tarafindan üstün yeteneklilerin en temel ihtiyaçları olarak belirtilmiştir. Bu konudaki görüşlerini R4 ve R6 şu şekilde ifade etmişlerdir:

Bence temel ihtiyaçları anlaşılabilmek ve farklı olduklarının kabul edilmesi. Farklılık derken olumlu anlamda, yani "senin neden farklı olduğunu biliyorum çünkü sen zekâ olarak, yetenek olarak çok üstünsün, işte bunları yaşayabilirsin çünkü farklı duyuyorsun farklı algılayabiliyorsun benden farklısın" şeklinde. Kabul edilme ihtiyaçları var. Ama o dengeyi sağlayabilmek için psikolojik danışman olarak da bence üstümüze düşen görevler var. Bencillikle ilgili sınırını ayarlayabilmemiz gerekiyor; yani çok abartılıyor. Farklısın o zaman sana bütün kapılar açılmalı, farklısın sen okul kurallarından muaf tutulmalısın ya da farklısın 
sonuna kadar hata yapabilirsin ya da hiç hata yapmayabilirsin gibi böyle keskin şeylerini törpülemek gerekiyor. (R4)

Öğretmenlerin onu anlaması, ona göre uygun etkinlikler sunması noktasında tabi sıkıntılar olabiliyor. Çünkü öğretmenler için de bunlar zor çocuklar oluyor. Farklı şeyler istiyor, farklı sorular soruyor, farklı taleplerle gidiyor öğretmen ona izin vermeyince çocuk bir bozguna uğruyor, sinirleniyor. (R6)

Yapılan görüşmelerde, üstün yeteneklilere özgü eğitim kurumları ve PDR programlarının öğrencilerin temel ihtiyaçları arasında görüldüğ̈ tespit edilmiştir. Daha az katılım olmakla birlikte üstün yetenekli öğrencilerin duygusal yönlerinin anlaşılması ve sevgi/sayg1 ihtiyaçları da yine bu başlık altında dile getirilen konulardır. Bu konudaki rehber öğretmen görüşlerinden bazıları şunlardır:

Bu çocukların farklı çalışmaları temel eğitim süreci içerisinde yapmaları çok zor, ne kadarını yapabilir. Evet gün içerisinde çocuğun nadiren alınıp, bazı derslerde ekstra çalışmalar yaparak yani onu sınıf ortamından çıkarıp farklı şeyler yaparak motive etmek amaçlı çalışmalar olabilir. Ama bunun dışında çocuğa farklı şeyler yapmak, farklı bakış açıları kazandırmak için BİLSEM'ler dışında farklı kurumlar olması gerektiğini düşünüyorum. (R5) Bence bu öğrencilerin daha farklı okullarda eğitim almaları gerekiyor, hani bunu tamamen ayrışma anlamında demiyorum ben, kendi arkadaşlarıyla beraber farklı eğitim almaları ve onlara yönelik yine farklı bir PDR programının olması gerektiğini düşünüyorum. (R2)

Üstün yetenekli öğrencilerin temel ihtiyaçlarının karşılanmasıyla ilgili olarak katılımcıların büyük bir kısmı, okul rehberlik servislerinin aile ve öğretmen bilgilendirmeleri yapabileceğini belirtmiştir. Bununla birlikte iki rehber öğretmen bireysel görüşme yapmanın, diğer iki rehber öğretmen ise yetenek alanlarını tanımanın daha yararlı uygulamalar olduğunu vurgulamışlardır.

Tablo 3. Üstün Yetenekli Öğrencilerin Temel İhtiyaçları ve Bu İhtiyaçların Karşılanmasında Rehber Öğretmenlerin Rolü

\begin{tabular}{|c|c|c|c|c|c|c|c|c|}
\hline Temel Íhtiyaçlant & R1 & $\mathrm{R} 2$ & $\mathrm{R} 3$ & $\mathrm{R} 4$ & R5 & R6 & R7 & $\mathrm{R} 8$ \\
\hline Yetenek alanlarının tanınması & $\checkmark$ & & & & & & & $\checkmark$ \\
\hline Anlaşılma ve farklı olduklarının kabul edilmesi & & & $\checkmark$ & $\checkmark$ & & $\checkmark$ & $\checkmark$ & $\checkmark$ \\
\hline Daha farklı okul ve kurumlarda öğrenim görme & & $\checkmark$ & & $\checkmark$ & $\checkmark$ & & & \\
\hline Farklı PDR programinin uygulanmas1 & & $\checkmark$ & & $\checkmark$ & & & & $\checkmark$ \\
\hline Sayg1 ve sevgi (diğer çocuklarla aynı) & & & $\checkmark$ & & & & & $\checkmark$ \\
\hline \multicolumn{9}{|l|}{ Rehberlik Servisinin Yapabilecekleri } \\
\hline Aile ve öğretmenlerin bilgilendirilmesi & $\checkmark$ & $\checkmark$ & $\checkmark$ & $\checkmark$ & $\checkmark$ & & $\checkmark$ & $\checkmark$ \\
\hline Bireysel görüşmelerin yapılması & & & & & $\checkmark$ & $\checkmark$ & & \\
\hline Özel ilgileri doğrultusunda yönlendirmelerin yapılması & $\checkmark$ & & & & & & & $\checkmark$ \\
\hline
\end{tabular}

\section{Üstün Yetenekli Öğrencilerin PDR İhtiyaçları ve Bu İhtiyaçların Karşılanması için Yapilan Uygulamalar}

Üstün yetenekli öğrencilerin PDR ihtiyaçlarının neler olduğu ve bu ihtiyaçları nasıl karşıladıkları rehber öğretmenlere sorulmuş, verdikleri cevaplar Tablo 4'te özetlenmiştir. Üstün yetenekli öğrencilerin farklı sorunları nedeniyle PDR hizmetlerine ihtiyaç duydukları konusunda bir katılımcı hariç diğerlerinin fikir birliği içinde oldukları görülmektedir. Rehber öğretmenlerin belirttikleri ihtiyaçların bir kısmı eğitsel alanla ilgili iken diğer kısmının kişisel ve sosyal alanla ilgili olduğu görülmektedir. Katılımcıların beşi, arkadaş ilişkileriyle ilgili sorunlara dikkat çekmiştir. Üstün yetenekli öğrencilerin arkadaş ilişkilerinde yaşadıkları sorunların; akranlarıyla anlaşamama, liderlik çatışmaları, normal gruptaki akranlarını küçük görme gibi çeşitli nedenlerden kaynaklandığı belirtilmektedir. Rehber öğretmenlerden bazılarının bu konudaki görüşleri aşağıda verilmiştir:

Bazılarında sosyal iletişim çok iyi değil. Hepsinin üstün yetenekli olması sosyal iletişimlerinin çok üst düzeyde olduğu, çok iyi diyaloglar kuracağı anlamına gelmiyor. Çok 
problem yaşıyorlar. Mesela Fen lisesinde, diyorlar ki "lider benim", o diyor ki "hayır benim" öbürü diyor ki "hayır benim". Tek başına kabul edilme ihtiyaçları çok yoğun, çatışmaları çok yoğun. Normal okullarda daha iyiler yani homojen gruplarda daha iyiler. Bir tarafin çok düşük bir tarafin çok yüksek olduğu gruplarda değil. Daha çok kabul görüyorlar. Üstün yetenekliler için iyi de normaller için sıkıntı olabiliyor, eğer biz onlarla çalışmayı bilmiyorsak ki çoğunlukla bilmiyoruz o zaman kantarın topuzu kaçıyor, normaller adına üzücü olabiliyor. (R4)

Özellikle bu küçük yaştaki, ilkokul grubundaki üstün yetenekli çocukların bir kısmının sosyal ilişkilerine baktığınızda, kendilerinden yaşça büyük kişilerle arkadaşlık yapıyorlar. Niye? Kendi yaşıtlarının onları anlayamadıklarını düşünüyorlar. Konuştukları zaman kendilerini kimler anlayabilecekse o kişilerle sohbet etmek, arkadaşlık kurmak istiyorlar. Çünkü kendi yaşındaki kişi onu anlayamıyor yani onun düşündügü, konuştuğu mevzular o yaştaki birisine çok şey geliyor, nasıl diyelim, saçma geliyor ya da anlamsız geliyor. İlgileri farklı oluyor o yaştaki öğrencilerin. (R8)

Diğer çocukları kendi seviyesinde görmüyor. Arkadaş ilişkilerinde zorlanıyor, özellikle üstün zekânın derecelerine göre, tabi iyiyse [zekâ puanı normalden çok yüksekse] zorlanıyor arkadaş ilişkilerinde. (R6)

Rehber öğretmenler ayrıca üstün yeteneklilik etiketinin öğrenciler üzerinde oluşturduğu olumsuz etkilerden bahsetmişlerdir. Buna bağlı olarak çevrenin beklentilerinin yükselmesi ve kendilerindeki mükemmeliyetçilik duygularına da dikkat çeken katılımcılar vardır. Öğrencilerin PDR gereksinim duydukları bu konularla ilgili öğretmen görüşlerinden bazıları şunlardır:

Arkadaş çevresinin bunu bildiğinde [üstün yetenekli olduğunu] o öğrenciye, normalde böyle bir şey olmaması gerekiyor ama, ders başarısı üzerinden yaklaşıldığını düşündüğünüzde o öğrencilerin psikolojilerinin ne boyutta olacağını az çok tahmin etmeniz zor değil. Bu yönde daha çok çalışma yapılması gerekiyor. O öğrencilerin diğerlerinden çok da farklı olmadığını ve yahut da bir alanda üstün yetenekli olmalarının tüm derslerinin 100 olacağı anlamına gelmediği hem öğrencilere hem öğretmenlere anlatılmalı. (R2)

Bir de üstün yeteneklilik toplumda bir dezavantaj değil avantajmış gibi algılanıyor. "Zaten sen üstün yeteneklisin daha ne istiyorsun" gibi bir şey oluyor. Mesela bize (BİLSEM'e) gelen öğrencilerin bir kısmı özellikle ilk yıllarda bir süre sonra okullarına gitmek istemiyorlar. Çünkü o çocuğun üstün yetenekli olduğu okulda duyulduktan sonra öğretmenlerin onlardan beklentileri yüksek oluyor. Onlar da çocuk, davranışal ve duygusal olarak hata yapabiliyorlar, yaramazlık yapabiliyorlar, başkalarının zayıf yönlerini gördükleri zaman karşılarındakini hırpalayabiliyorlar. Ama öğretmenler "eğer üstün yetenekliysen bu sınıfta soruyu önce sen çözeceksin, en hızlı sen olacaksın" diyor veya hata yaptıkları zaman "sen nasıl üstün yeteneklisin" gibi onları sınıf ortamında rencide edici, hırpalayıcı davranışlarda bulunuyorlar. Bu çocuklar açısından hoş bir durum değil. (R8)

Tablo 4. Üstün Yetenekli Öğrencilerin PDR İhtiyaçları

\begin{tabular}{|c|c|c|c|c|c|c|c|c|}
\hline & R1 & $\mathrm{R} 2$ & R3 & R4 & R5 & R6 & $\mathrm{R} 7$ & $\mathrm{R} 8$ \\
\hline Pek farklı ihtiyaçları yok/diğer çocuklarla aynı & $\checkmark$ & & & & & & & \\
\hline Sınıfta sıkılma ve buna bağlı disiplin sorunları & & & & & $\checkmark$ & & & \\
\hline Arkadaş ilişkilerinde sorunlar & & $\checkmark$ & & $\checkmark$ & $\checkmark$ & & $\checkmark$ & $\checkmark$ \\
\hline Popülerlik, ön planda olma & & & & & $\checkmark$ & $\checkmark$ & & \\
\hline Üstün yeteneklilik etiketiyle baş etme & & $\checkmark$ & & & $\checkmark$ & & & $\checkmark$ \\
\hline Kuralları sorgulama / yetișkinlerle çatıșma & & & & $\checkmark$ & $\checkmark$ & & $\checkmark$ & \\
\hline Sinav kayg1s1 & & & & & $\checkmark$ & & $\checkmark$ & \\
\hline Mükemmeliyetçilik (kendileri ve diğerleri) & & $\checkmark$ & & & & & $\checkmark$ & $\checkmark$ \\
\hline Motivasyonsuzluk ve dikkat eksikliği & & & & & $\checkmark$ & & $\checkmark$ & \\
\hline Okula gitmek istememe & & & & & & & & $\checkmark$ \\
\hline Duygusal yönlerinin anlaşılmaması & & & $\checkmark$ & & & & & $\checkmark$ \\
\hline
\end{tabular}


ALTUN, Fatma ve Hikmet YAZICI (2020). “Rehber Öğretmenlerin Üstün Yetenekli Öğrencilere Sunulan Psikolojik Danışma ve Rehberlik Hizmetleri ile İlgili Görüşleri”, Ma vi Atlas, 8(1): 81 -106

Tablo 5'te rehber öğretmenlerin üstün yetenekli öğrencilerinin PDR ihtiyaçlarını karşılamaya dönük yaptıkları çalışmalar sunulmaktadır. Buna göre öğretmenlerin tümü veli görüşmeleri yaptıklarını belirtmişlerdir. Öğrencilerin ihtiyaçlarını karşılamada rehber öğretmenlerin en sık kullandıkları yöntemlerin bireysel görüşmeler ve öğretmen bilgilendirmeleri olduğu görülmektedir. Bununla birlikte grup çalışmaları ve akran danışmanlığı gibi özel etkinliklerin de planlandığ tespit edilmiştir. Öğretmenlerden bazıları ise sadece standart PDR hizmetlerini uyguladıklarını belirtmişlerdir.

Tablo 1. Üstün Yetenekli Öğrencilerin PDR İhtiyaçlarına Dönük Yapılan Çalışmalar

\begin{tabular}{|c|c|c|c|c|c|c|c|c|}
\hline & R1 & $\mathrm{R} 2$ & R3 & $\mathrm{R} 4$ & R5 & R6 & R7 & $\mathrm{R} 8$ \\
\hline Yönlendirme, eğitim planlanmas1 & $\checkmark$ & & & & & & & \\
\hline Veli görüşmeleri & $\checkmark$ & $\checkmark$ & $\checkmark$ & $\checkmark$ & $\checkmark$ & $\checkmark$ & $\checkmark$ & $\checkmark$ \\
\hline Standart PDR hizmetleri/özel bir uygulama yok & $\checkmark$ & $\checkmark$ & & & & & & \\
\hline Bireysel görüşmeler & & $\checkmark$ & & $\sqrt{ }$ & $\checkmark$ & $\checkmark$ & $\checkmark$ & $\checkmark$ \\
\hline Grup çalışmaları & & & & & & $\checkmark$ & & \\
\hline Akran danışmanlığ1 & & $\checkmark$ & & & $\checkmark$ & $\checkmark$ & & \\
\hline $\begin{array}{l}\text { Öğretmen görüşmeleri, bilgilendirme toplantıları, } \\
\text { okul ziyaretleri }\end{array}$ & $\checkmark$ & & & $\checkmark$ & $\checkmark$ & $\checkmark$ & $\checkmark$ & $\checkmark$ \\
\hline
\end{tabular}

\section{Okul/BİLSEM Rehberlik Programının Üstün Yeteneklilerin İhtiyaçlarını Karşılama Durumu}

Görüşme sırasında rehber öğretmenlere yöneltilen sorulardan bir diğeri, uyguladıkları rehberlik programının üstün yetenekli öğrencilerin ihtiyaçlarını ne ölçüde karşıladığı ve programdaki hangi bölümünün bu öğrencilere daha çok hitap ettiğidir. Tablo 6'da görüldüğü gibi rehber öğretmenlerin bu konuyla ilgili görüşleri farklılık göstermektedir. Öğretmelerden üçü okullardaki programın yeterli olmadığ1 ve tamamen farklı bir program uygulanması gerektiğini belirtmektedir. Bununla birlikte R1 ve R2, uyguladıklar1 mevcut programın üstün yetenekliler de dahil olmak üzere tüm öğrencilere hitap ettiği ve yeterli olduğu görüşündedirler. Diğer rehber öğretmenler ise rehberlik programında bu öğrencilere dönük özel etkinliklere yer verdiklerini veya verilmesi gerektiğini belirtmişlerdir. Konuyla ilgili görüşlerden bazıları aşağıdaki gibidir:

Programda onlar için özel bir alan yok, diğer öğrenciler rehberlik etkinliklerinden nasıl faydalanıyorsa onlar da faydalanıyorlar. Açıkçası programda ayrım yok ama destek eğitim odasinda özel bir uygulama var. (R1)

Yeni program aslında onlar için faydalı ama içerik nasıl dolduruluyor o önemli. Çünkü çocuğun beklentisi diğerleri gibi değil, algılaması çok daha analitik olduğu için sorguluyor. (R4)

Rehberlikte yaptı̆̆ımız yıllık program içerisindeki etkinlikler onlara yeterli geliyor. Ben haftada bir saat her sınıfta derse giriyorum. Girdiğim derslerde öğrencileri etkinliklerle farklı açılardan yakalamaya çalışıyorum. Sadece yıllık plana koyduğum etkinliklerle değil, aynı zamanda değerler eğitimiyle ilgili, dikkat çalışmalarıyla ilgili, başka şeyleri interaktif şekilde yapmaya çalışıyorum. Onların zaten ilgilerini çekiyor, hatta çok seviyorlar. (R5)

Rehber öğretmenlere göre, rehberlik programında üstün yetenekli öğrencilere en fazla hitap eden bölüm bireysel görüşmelerdir. Bunun yanı sıra aile eğitimleri, eğitsel ve mesleki rehberlik hizmetleri ile ilgili bölümlerin de üstün yetenekli öğrencilerin ihtiyaçlarını karşılamada yeterli oldukları belirtilmiştir.

Tablo 6. Okul/BİLSEM Rehberlik Programının Üstün Yetenekli Öğrencilerin İhtiyaçlarını Karşılama Durumu

\begin{tabular}{lllllllll}
\hline Rehberlik Programinin Durumu & R1 & R2 & R3 & R4 & R5 & R6 & R7 & R8
\end{tabular}


ALTUN, Fatma ve Hikmet YAZICI (2020). “Rehber Öğretmenlerin Üstün Yetenekli Öğrencilere Sunulan Psikolojik Danışma ve Rehberlik Hizmetleri ile İlgili Görüşleri”, Ma vi Atlas, 8(1): 81 -106

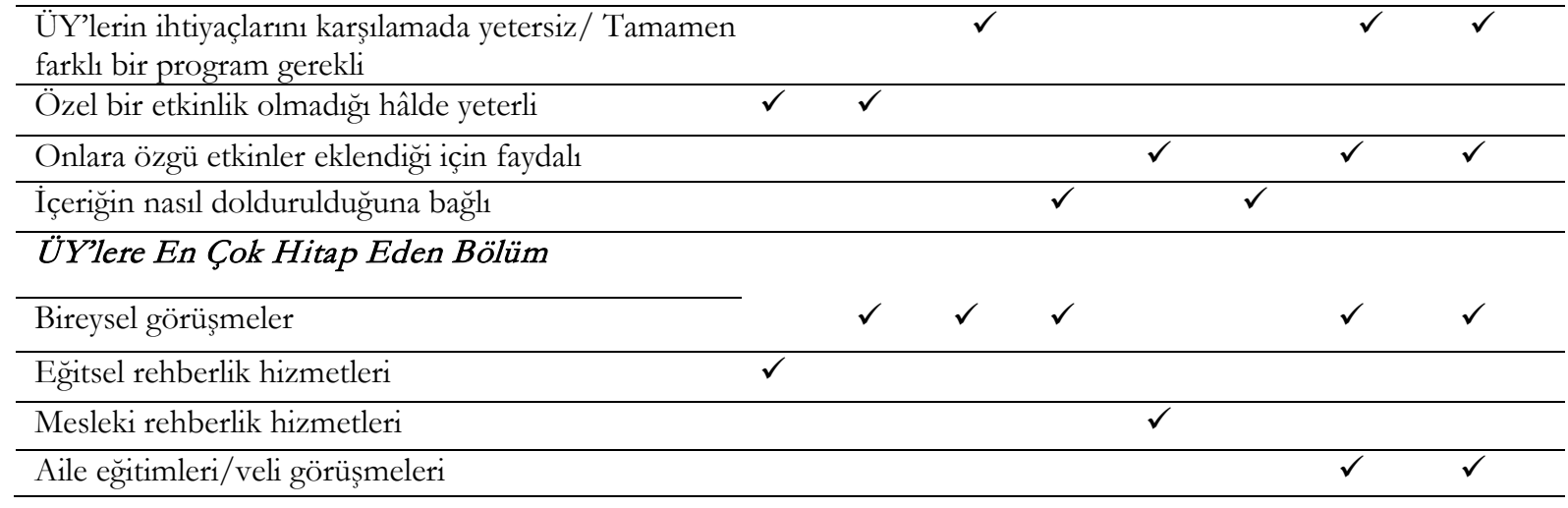

Rehber Öğretmenlerin Üstün Yetenekli Öğrencilerinin İhtiyaçlarını Nasıl Anladıklarıyla İlgili Görüşleri

Tablo 7'de rehber öğretmenlerin üstün yetenekli öğrencilerin ihtiyaçlarını nasıl anladıklarıyla ilgili görüşleri özetlenmektedir. Rehber öğretmenlerin çoğunun diğer öğretmenlerin görüş ve gözlemlerinden yola çıktıkları bunun yanı sıra kendi görüşme ve gözlemlerine ve veli beyanlarına dayalı olarak da öğrencilerin ihtiyaçlarının farkında oldukları tespit edilmiştir. Katılımcılardan birkaçı ise öğrencilerin kendilerinin rehberlik servisine başvurduğunu veya arkadaşlarının beyanlarını dikkate aldıklarını belirtmişlerdir. Bununla birlikte öğrenci tanıma fiş veya formların kullanımının oldukça az olduğu görülmektedir.

Tablo 7. Rehber Öğretmenleri Üstün Yetenekli Öğrencilerin İhtiyaçlarını Anlamayla İlgili Görüşleri

\begin{tabular}{|c|c|c|c|c|c|c|c|c|}
\hline & R1 & R2 & R3 & $\mathrm{R} 4$ & $\mathrm{R} 5$ & R6 & R7 & R8 \\
\hline Bireysel görüşme ve gözlemler & & $\sqrt{ }$ & & $\checkmark$ & $\checkmark$ & $\checkmark$ & $\checkmark$ & $\checkmark$ \\
\hline Öğretmen görüş ve gözlemleri & $\checkmark$ & $\sqrt{ }$ & $\checkmark$ & $\sqrt{ }$ & $\checkmark$ & & $\checkmark$ & $\checkmark$ \\
\hline Veli beyanları & $\checkmark$ & $\checkmark$ & $\checkmark$ & & & & $\checkmark$ & $\checkmark$ \\
\hline Öğrencilerin kendi başvuruları & $\checkmark$ & & & & & & $\checkmark$ & $\checkmark$ \\
\hline Arkadaşlarının beyanları & & $\checkmark$ & & $\checkmark$ & $\checkmark$ & & & \\
\hline Öğrenci tanıma fişleri ve formlar & & & $\checkmark$ & & & & & $\checkmark$ \\
\hline
\end{tabular}

Rehber Öğretmenlerin Üstün Yetenekliler için Kullandıkları Yöntemlerden Başarı1ı veya Başarısız/Kullanışsız Buldukları Aktivite ve Roller

Araştırmaya katılan rehber öğretmenlerden üstün yetenekli öğrencilere dönük kullandıkları aktivite ve rolleri değerlendirmeleri istenmiş, verdikleri cevaplar Tablo 8'de özetlenmiştir. Öğretmenlerin en faydalı bulduğu yöntemler bireysel ve veli görüşmeleridir. Bununla birlikte grup etkinliklerinin üstün yetenekli öğrenciler için oldukça yararlı olduğu yönünde görüşler vardır. $\mathrm{Bu}$ grup etkinlikleri içerisinde, grup rehberliği, drama çalışmaları ve çeşitli sosyal aktiviteler yer almaktadır. Katılımcılardan R6 ve R7 grup çalışmalarıyla ilgili görüşlerini şu şekilde ifade etmektedirler:

Drama etkinlikleri çok faydalı bence, bir de çevre gezileri çok faydalı. Gerçekten, eğitimi sınıflardan çıarmak lazım. Üstün yetenekliler için bu çok gerekli özellikle. (R7)

Mesela iki kez onun [üstün yetenekli öğrencinin] sorunları dolayısıyla grup çalışması yaptım.

Sınıflarındaki çatışma yaşadığı kızlarla toplandık. Kızlar duygularını dile getirdi, o duygularını dile getirdi. Gerçekten çok rahatladılar. Onlar da dediler çok iyi geldi diye. Şuan çok iyi gidiyor yani. (R6)

Rehber öğretmenlerden bazıları ise öğrencilerin yeteneklerini sergileyebilecekleri ortamlar oluşturma ve okulda yapılan çeşitli etkinliklerde sorumluluk almalarını sağlama gibi aktiviteleri faydalı bulmaktadır. Bu konuyla ilgili olarak R5 ve R6'nın görüşleri şu şekildedir: 
Bazen okul içerisinde uygulayacağım seminerlerde ya da veli seminerlerinde yapacağım çalışmalara onları katmaya çalışıyorum farklı açlardan. Onları motive etmek amaçlı, çünkü bu tarz çocuklar kendilerini göstermeyi çok severler, kendi yaptıkları şeyle önde olmaları çok hoşlarına gider. Mesela bir veli seminerimizin sonunda onlara hazırlattığım bir resim çalışması vardı, onların resimlerini orda sunum arasında kullandık ve çocuklar çok motive oldular. Bu anlamda çok destekleyici oluyor. Hem onlarla benim ilişkim açısından çok bağlayıcı oluyor hem de çocukların buradaki düzenleri, ilerlemeleri açısından çok faydalı oluyor. (R5)

Mesela hobi çalıșmaları yaptırıyorum, değerler eğitimi çalıșmasına onu katıyorum ve böylece ön plana çıkması da ona iyi geldi. Yani sonuçta bu çocuk sıradan değil ki sıradan olmayı nasıl kabullensin, nasıl katlansın. $\mathrm{Bu}$ ona çok iyi geldi. Yani işler veriyorum görevler veriyorum. Sürekli buradadır hatta ben ona esprili yaklaşırım, asistanım falan derim bu onun çok hoşuna gidiyor. (R6)

Tablo 8'de görüldüğü gibi rehber öğretmenlerden bazıları üstün yetenekli öğrencilerle çalışırken faydalı olan danışman tutumları ve rollerine değinmişlerdir. Buna göre danışmanın alanında yeterli olması, kendini geliştirmesi üstün yetenekli öğrencilere hitap etme açısından önemli görülmektedir. Ayrıca öğrenciyi merkeze alan ve empatik bir yaklaşımın da faydalı olduğu belirtilmiştir. Bu konuya dikkat çeken R4 ve R8 görüşlerini şu şekilde dile getirmişlerdir:

Rehberlik programinda bazı gruplara gireriz hani daha kulaktan dolma daha geleneksel verilerle şey yapılabilir, yani daha toplumsal örneklerle grubu alır götürürsün çok muhteşem gelir o konu onlara. Ama üstün yeteneklilerin içinde olduğu grup daha veri istiyor, daha bilimsel bilgi istiyor. Mesela hani şu öğrenilmiş çaresizlikle ilgili bir örnek vardır ya bir kafese maymunları koymuşlar, su dökmüşler vesaire... Bunu anlatıyorsunuz, grupta eğer üstün yetenekli bir çocuk yoksa çok ilgi çekici ve şey geliyor "Aa ne kadar enteresan”. Orda kimse bu çalışmayı kim yapmış, ne zaman yapmış, hangi üniversitede yapılmış gibi sorular sormuyor. Ya da "Buna benzer çalışmalar var mı?" diyen bir öğrenciyle karşılaşmıyoruz. Ama grupta üstün yetenekli varsa onlar sorguluyorlar. Ben bunun için araştırma yapmak zorunda kalıyordum. Şiirden bile örnek verecek olsam "Orhan Veli şu kitabındaki şiirinde şöyle der değil mi?” dediğimde o zaman size daha kendileri gibi bakıyorlar, daha yetkin görüyorlar, daha çok kabul ediyorlar. Benim gibi, bu da zeki diyorlar sayg1 duyuyorlar. (R4) Yetişkinler çocuklardan kendi koydukları kurallara uymalarını bekliyor, yani yetişkinlerin kurallarına, ama çocuklarla konuştuğunuz zaman onlarında kendi iç dünyalarında kurdukları bir dünyaları var onun gerçekleşmesini istiyorlar. Çoğu zaman biz öğrenciden yana oluyoruz. Öğrenci mutlu olsun. Zaten öğrenciden yana olup onu anladığınızı ifade etmezseniz o öğrenci bir daha size gelmeyecektir. Yani bir şekilde onların duygu dünyasına girmek zorundasınız ki başarılı olasınız. Üstün yeteneklilerin kişilik özelliklerini bilmezseniz ona göre yaklaşmazsanız kesinlikle sizinle işbirliğine yanaşmazlar. Mesela psikolojik danışmanlığın bir kısmı bilgi aktarma işidir, bilgi eksikliğinden kaynaklanan sıkıntılar olduğu zaman sorun oluyor. Bu öğrencilere bilgiyi daha bilimsel, ispatını yaparak sunduğunuz zaman daha ikna edici oluyor ve iş birliğine yaklaşıyorlar. (R8)

Araştırmaya katılan rehber öğretmenlerden ikisi üstün yetenekli öğrencilere dönük aktivite ve rollerle ilgili bilgi sahibi olmadığını belirtmiştir. Bununla birlikte katılımcıların üstün yetenekli öğrencilerine dönük başarısız oldukları ya da kullanışsız buldukları aktivitelerin; sıradan/ezberci etkinlikler, aile desteğinin sağlanamaması ve bireysel görüşmenin devamlılı̆̆ının sağlanamaması olduğu görülmektedir.

Tablo 8. Üstün Yetenekli Öğrenciler için Başarılı veya Başarısız Bulunan Aktivite ve Roller

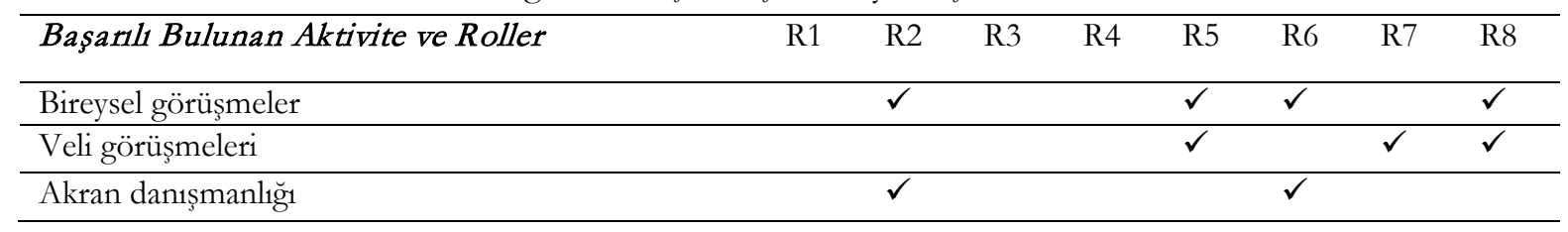


ALTUN, Fatma ve Hikmet YAZICI (2020). “Rehber Öğretmenlerin Üstün Yetenekli Öğrencilere Sunulan Psikolojik Danışma ve Rehberlik Hizmetleri ile İlgili Görüşleri”, Ma vi Atlas, 8(1): 81 -106

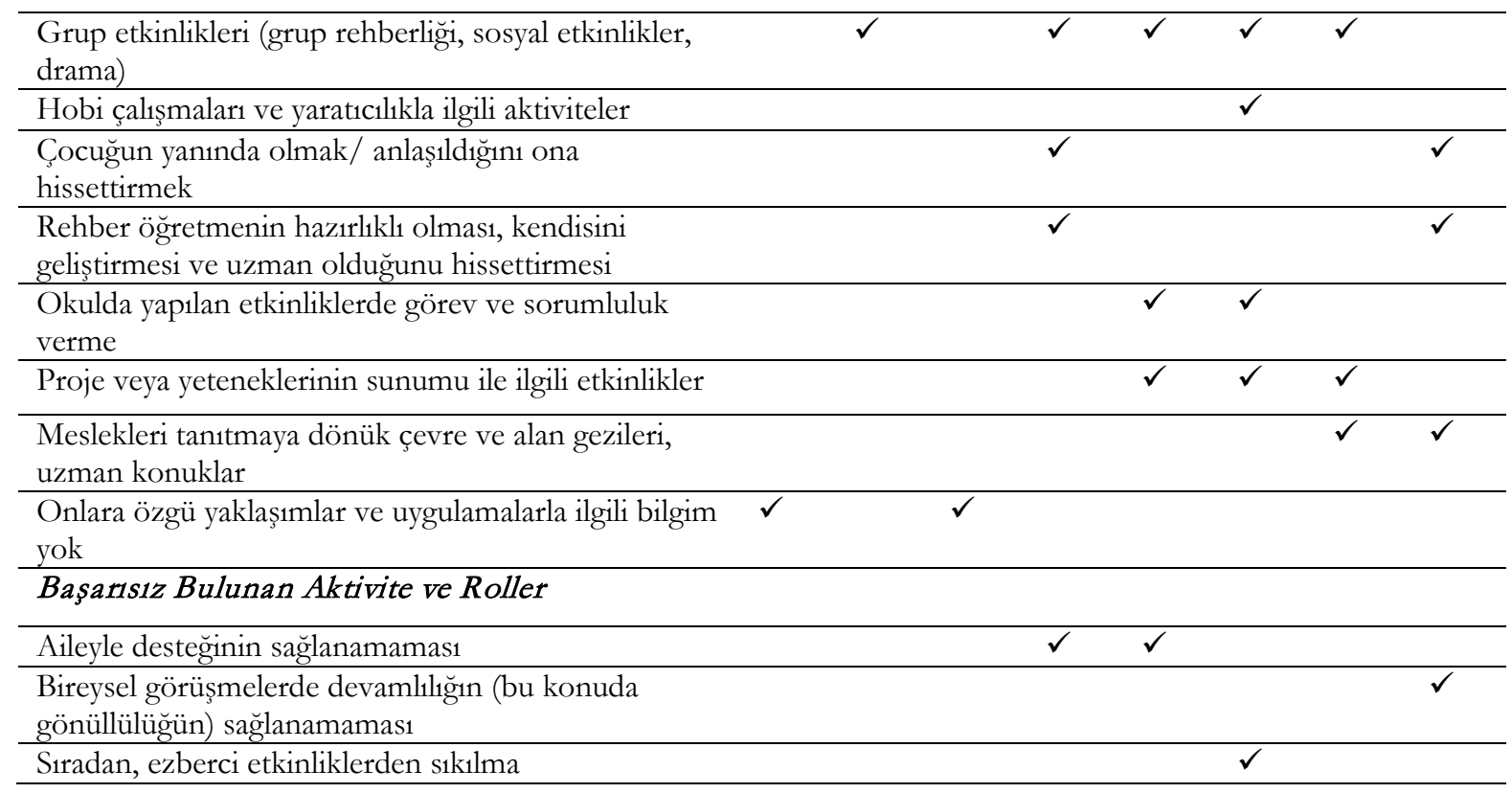

\section{Üstün Yeteneklilerle Çalışan Rehber Öğretmenlerin Eğitimlerine ve Hazırlıklarına İlişkin Görüşler}

Görüşmeler sırasında katılımcılara; üstün yeteneklilerle çalışan rehber öğretmenlerin eğitimi ve hazırlı̆̆ı ile ilgili nelerin önemli olabileceği sorulmuş ve alınan cevaplar Tablo 9'da özetlenmiştir. Katılımcılar üstün yetenekliler konusunda eğitimciler ve okul psikolojik danışmanları arasında bilgi eksikliği olduğu konusunda fikir birliği içerisindedirler. Bu bilgi eksikliklerinin giderilmesine ilişkin önerileri ise farklılaşmaktadır. Rehber öğretmenlerden dördü, belli zaman aralıklarında üstün yetenekli öğrencilerle ilgili hizmet içi eğitimlerin düzenlenmesi gerektiğini belirtirken, üçü bu eğitimlerin lisans düzeyinde ders olarak okutulması gerektiğine vurgu yapmıştır. Ayrıca katılımcılardan bazıları, bu eğitimlerin psikolojik danışmanların yanı sıra tüm eğitimcilere yönelik olmasının gerektiğini belirtmişlerdir. R1ve R2 bu konudaki görüşlerini şöyle ifade etmektedirler:

Kesinlikle bu konuda lisansta onlara ait bir dersin olması gerekiyor, özel eğitimin içerisinde değil de sadece üstün yeteneklilerle, özellikleriyle ya da onlarla çalışırken karşılaşılabilecek sorunlarla ve çözüm önerileriyle ilgili. Ya da biraz önce bahsettiğimiz aktiviteler ve roller gibi buna benzer konuların olduğu bir dersin olması gerekli çünkü bu konuda eksik olduğumuzu düşünüyorum. Artık hemen hemen her okulda tanılanmış üstün yetenekli öğrenci var. Bizim daha donanımlı olmamız gerektiğini düşünüyorum, bu konuda eksikliğimiz olduğunu hissediyorum. Hizmet içinde bu eğitimler karşılanmıyor, genelde kısa süreli ve kalabalık gruplar oluyor o nedenle ayrı bir ders olsa daha iyi olur. (R1)

Özellikle belki bunu vurgulamak gerekiyor, üniversitelerde, şuan bilmiyorum müfredatta var mı yok mu ama, özellikle üstün yeteneklilerle ilgili en azından bir dönem bir ders olması gerekiyor. Bu derste psikolojik danışmanlara bu konuyla ilgili aynnntılı bilgiler verilmesi gerekiyor. Aslında yapılması gereken şu, üstün yeteneklilerin eğitimiyle ilgili dersin PDR alanında zorunlu olması gerekiyor ve özellikle diğer branşların formasyon eğitimlerinde almaları gereken kredi veya dersler içerisinde bu dersin de olması gerekiyor. Tabi ki bunun kredisi, kaç saat olduğu tartış1ır. Ama bu daha ikinci aşamada. Bu eğitim daha bize, psikolojik danışmanlara verilmezken onlara verilmesi lüks kalıyor. (R2)

Rehber öğretmenlerin eğitimi ve hazırll̆ğ konusunda katılımcıların bazıları tanılama araçlarıyla ve mesleki etikle ilgili eğitimlere ağırlık verilmesinden bahsetmişlerdir. Bununla birlikte öğrencilerin sosyal-duygusal gelişimleri hakkında bilgi sahibi olunması gerektiği ve bu konuda hazırlanmış kaynakların faydalı olabileceği belirtilmiştir. R3 bu konuyla ilgili görüşlerini şu şekilde ifade etmiştir: 
ALTUN, Fatma ve Hikmet YAZICI (2020). “Rehber Öğretmenlerin Üstün Yetenekli Öğrencilere Sunulan Psikolojik Danışma ve Rehberlik Hizmetleri ile İlgili Görüşleri”, Ma vi Atlas, 8(1): 81 -106

Bu alanda kaynak çok ama bir de okullarda ne yapabileceğimizle ilgili kaynak, uygulama alanına yönelik kaynak sağlanmalı. Şimdi ben birkaç tane doküman bulmuştum, ana sınıfındaki öğrenci için, işte yetenekli midir diye sorulduğunda. Ama çok da fazla bir şey bulamadım. Bilgilendirici şeyler vardı ama böyle çocuklara ne tarz çalışmalar yapabiliriz ile ilgili çok fazla bir şey bulamadım. (R3)

Tablo 9. Üstün Yetenekli Öğrencilerle Çalışan Rehber Öğretmenlerin Eğitimleri ve Hazırlıklarına İlişkin Görüşleri

\begin{tabular}{|c|c|c|c|c|c|c|c|c|}
\hline & R1 & $\mathrm{R} 2$ & R3 & R4 & R5 & R6 & $\mathrm{R} 7$ & R8 \\
\hline Özel eğitim dersi dışında ayrı bir ders olmalıdır & $\checkmark$ & & & $\checkmark$ & & & & \\
\hline $\begin{array}{l}\text { Üstün yeteneklilik lisansta PDR alanında zorunlu, } \\
\text { diğer bölümlerde seçmeli ders olmalıdır }\end{array}$ & & $\checkmark$ & & & & & & \\
\hline $\begin{array}{l}\text { Eğitim süreci içerisindeki herkes bu konudaki } \\
\text { eğitimlerden geçmelidir }\end{array}$ & $\checkmark$ & & & & $\checkmark$ & & $\checkmark$ & \\
\hline $\begin{array}{l}\text { Belli periyotlarda hizmet içi eğitimler } \\
\text { düzenlenmelidir }\end{array}$ & & $\checkmark$ & $\checkmark$ & & & & $\checkmark$ & $\checkmark$ \\
\hline $\begin{array}{l}\text { Bölgedeki rehber öğretmenleri yönlendirebilecek } \\
\text { koordinatörler/uzmanlar yetiștirilmelidir }\end{array}$ & & & $\checkmark$ & & & & & $\checkmark$ \\
\hline $\begin{array}{l}\text { Tanılama araçlarının kullanımı ve yorumlanmasıyla } \\
\text { ilgili eğitimler verilmeli ve etik beceriler } \\
\text { kazandırılmalıdır }\end{array}$ & & & & $\checkmark$ & & & $\checkmark$ & $\checkmark$ \\
\hline $\begin{array}{l}\text { Uygulamaya dönük kaynaklar (kitap, broşür, } \\
\text { modüller) temin edilmelidir }\end{array}$ & & & $\checkmark$ & & & & & \\
\hline $\begin{array}{l}\text { Özellikle çocukların duygusal yönleri ve } \\
\text { karşılaşabilecekleri problemler hakkında bilgi sahibi } \\
\text { olunmalıdır }\end{array}$ & & & & & $\checkmark$ & $\checkmark$ & & \\
\hline
\end{tabular}

\section{Üstün Yetenekliler Programının ve Okuldaki Uygulamaların Üstün Yetenekli Öğrencilerin Psiko-Sosyal Gelişimlerine Hitap Etme Durumu}

Araştırmaya katılan rehber öğretmenlere özel eğitim programlarında ve normal okullarda uygulanan programların üstün yetenekli öğrencilerin psiko-sosyal gelişimlerine ne ölçüde hitap ettiği sorulmuştur. Verdikleri cevabın ardından bu durumun nasıl sağlandığı veya ne gibi değişikliklerin yapılması gerektiğiyle ilgili bir ek soru yöneltilmiştir. Öğretmenlerden gelen cevaplar Tablo 10 ve 11'de özetlenmiştir. Tablo 10'da görüldüğü gibi üstün yeteneklilere özel eğitim sunulan programlarda bu öğrencilerin psiko-sosyal ihtiyaçlarının dikkate alınma durumu üç farklı şekilde değerlendirilmektedir. Rehber öğretmenlerden bir kısmı mevcut programın psiko-sosyal ihtiyaçlarına hitap ettiğini söylerken bir kısmı ise kısmen hitap ettiğini belirtmektedir. Rehber öğretmenlerden üçü ise programın yeterli olmadığını, öğretmen eğitimleri ve farklı etkinliklerle yeniden düzenlenmesi gerektiğini belirtmektedir. Bu konuyla ilgili görüşlerden bazıları aşağıdaki gibidir:

Hitap ettiğini düşünüyorum genel olarak. Mesela destek eğitiminde diyelim ki uyum programına alınıyorlar iletişim dersi görüyorlar, grupla çalışma, problem çözme vb. bunlar mesela bir basmak. Sonra BYF programinda (Bireysel Yetenekleri Fark Ettirici Program) özel olarak hangi alanda daha iyi olduklarını çözümlemeleri anlamında çok güzel. Yani çocuk kendini daha iyi fark ediyor, yeteneklerini tanıyor bu da doğal olarak psiko-sosyal gelişimlerini olumlu etkiliyor. Büyük değişim oluyor çocuklarda (süreç içinde). Yani çok değişiyorlar bakıyorsun daha olgunlaşıyorlar, tabi yaşı da ilerliyor bir de buranın daha iyi farkina variyorlar. (R7)

Evet BİLSEM hitap ediyor, çocuklar mutlu oluyor. Özellikle küçük yaşlarda. Ama her yll sorumlulukları arttığ için özellikle ortaokul evresinde maalesef bizim eğitim sistemimizde bir de sınav olduğu için, SBS/OKS (Seviye Belirleme Sınav1/Ortaöğretim Kurumları Seçme ve Yerleştirme Sınavı) gibi, o evrede çocukların artık pilleri bitiyor. Ortaokul evresindeki ögrrencilerim artık aileyle kavga halinde oluyor. Aileler gitmesini istiyor fakat çocuk istemiyor çünkü yoruluyor. Çocuklar haklı, zaten hepsi bıraktı sekizinci sınıfta (R5). 
Yani severek gidiyorlar BİLSEM'e benim öğrencilerim. Oranın onlara öyle bir faydası var, şöyle ki kendi gibi çocuklar var. Yani o yüzden oranın onlara iyi geldiğini düşünüyorum. (R6)

Ben bugün burada çalışıyorum yarın BİLSEM'de çalışabilirim ama bu benim daha çok yeterliğe sahip olduğumu gösterir mi? Önceden onların uyguladığ1 iki haftalık bir eğitimleri vard1, şuan öyle bir kriter yok. Bir kere onların uyguladığı özel bir programları var mı? Yok ki. (R4)

Ben birçok öğrencinin verimli bir şekilde BİLSEM'lerden ve oradaki çalışmalardan yeterince faydalanamadığını düşünüyorum. Belki yine oradaki alt yapıdan kaynaklanabilir veya onların müfredatından, programından kaynaklanabilir. Ama çok verimli bir şekilde yürütüldügünü düşünmüyorum. Mesela buradaki öğrencilerden (BİLSEM'e gidenlerden) ben örnek vereyim; buradaki öğrenciler birbirlerini bile tanımıyorlar. Gerçi iki tanesi aynı alanda ama onlardan alt sınıftaki öğrencilerin hangi alanda olduğunu bile bilmiyorlar. Demek ki bu şunu gösteriyor; orda bu öğrencilerin birbiriyle herhangi bir ilişkisi yok veya ortak bir çalışmaları yok, bir faaliyet yok diye ben bir çıkarımda bulunuyorum. (R2)

Tablo 10. Üstün Yetenekliler Programının Öğrencilerin Psiko-Sosyal Gelişimlerine Hitap Etme Durumu

\begin{tabular}{|c|c|c|c|c|c|c|c|c|c|}
\hline $\begin{array}{l}\text { ÜY Programları } \\
\text { (BİLSEM/Destek } \\
\text { Eğitimi ya da Bireysel } \\
\text { Eğitim Planı [BEP]) }\end{array}$ & $\begin{array}{l}\text { Nasıl/Nelerin Değişmesi } \\
\text { Gerekiyor }\end{array}$ & R1 & $\mathrm{R} 2$ & R3 & $\mathrm{R} 4$ & R5 & R6 & R7 & $\mathrm{R} 8$ \\
\hline \multirow[t]{2}{*}{ Hitap Ediyor } & $\begin{array}{l}\text { Ayrım yapılmıyor/tüm } \\
\text { öğrenciler gibi dikkate alınıyor }\end{array}$ & $\checkmark$ & $\checkmark$ & & & & & & \\
\hline & $\begin{array}{l}\text { ÜY'e özgü farklı etkinlikler } \\
\text { uygulanıyor }\end{array}$ & & & $\checkmark$ & & & & $\checkmark$ & $\checkmark$ \\
\hline \multirow[t]{2}{*}{ Kismen Hitap Ediyor } & Eğitsel alanın gerisinde kalıyor & $\checkmark$ & & & & & & & \\
\hline & $\begin{array}{l}\text { Özellikle küçük yaşlardakilere } \\
\text { hitap ediyor }\end{array}$ & & & & & $\checkmark$ & $\checkmark$ & & \\
\hline \multirow[t]{2}{*}{ Hitap Etmiyor } & $\begin{array}{l}\text { Öğretmenlerin eğitimi yeterli } \\
\text { değil }\end{array}$ & & & & $\checkmark$ & & $\checkmark$ & & \\
\hline & Farklı etkinlikler yapılmalı & & $\checkmark$ & & & & & & \\
\hline
\end{tabular}

Öğrencilerin hâlen devam etmekte oldukları okullardaki programların üstün yetenekli öğrencilerin psiko-sosyal gelişimlerine hitap etme durumuyla ilgili rehber öğretmen görüşleri de yine üç kategori altında toplanmaktadır. Fakat Tablo 11'de görüldüğü gibi okullarındaki programın üstün yeteneklilerin psiko-sosyal gelişimlerine hitap ettiğini düşünen öğretmen sayısı yalnızca birdir. Katılımcıların çoğu programın öğrencilerin psiko-sosyal gelişimlerine hitap etmediğini düşünmekte ve bu durumun değiştirilmesi için farklı öneriler sunmaktadırlar. Bu öneriler içerisinde rehber öğretmenlerin fikir birliği gösterdiği ve öncelikli olarak belirttikleri alan; eğitimcilerin bu konuyla ilgili eğitimidir. R3 ve R4 bu konudaki görüşlerini şu şekilde ifade etmektedirler:

Biz her zaman yeterli olamayabiliyoruz. İşte; bu çocuğa şöyle yaklaşılmalı, çocuğun gelişim düzeyi bu gibi ne kadar söylersek söyleyelim sonuçta çocukla birebir ilişkide olan öğretmen. Yani sınıf öğretmenlerinde bir farkındalık geliştirilebilirse daha etkili olur. (R3)

Tabi ki psiko-sosyal özelliklerinin dikkate alındığını düşünmüyorum, hiçbir zaman alınmadı. Yani yönetmelikteki görev ve sorumluluklar bile çok açık uçlu bırakılmış, istediğiniz zaman dışarıda tutabilirsiniz bu öğrencileri. Öncelikli olarak eğitim verilmesi gerekiyor, sadece psikolojik danışmanlara değil tüm öğretmenlere kesinlikle eğitim verilmeli. Tanılanmamış olması bu öğrencilerle çalışmadığınız anlamına gelmiyor. (R4)

Yani eğitim fakültelerinde üstün yeteneklilerle ilgili kesinlikle bilgi verilmeli, özellikleri anlatılmalı, ipuçları nelerdir nasıl anlarsınız bu çocukları, nasıl tanırsınız nasıl yaklaşmanız gerekli bir öğretmen olarak ya da çocuğa nasıl hitap edebilirsiniz, bunlar verilmeli. Ya da hizmet içi eğitimlerle öğretmenler bilgilendirilebilir. Aslında lisans düzeyindeki dersler çok 
ALTUN, Fatma ve Hikmet YAZICI (2020). “Rehber Öğretmenlerin Üstün Yetenekli Öğrencilere Sunulan Psikolojik Danışma ve Rehberlik Hizmetleri ile İlgili Görüşleri”, Ma vi Atlas, 8(1): 81 -106

etkili olur çünkü öğretmenliğe başlamadan önce bunları öğrenerek alana gelir ama alanda da bu bilgileri unutma durumu söz konusu oluyor. O zaman da bu tarz hizmet içi eğitimler devreye girebilir. (R7)

Rehber öğretmenlerden bazıları ise bu konudaki eksikliklerin giderilmesi için akademisyen desteğine ihtiyaç duyduklarını vurgulamışlardır. Öğretmenlerin bununla ilgili ifadeleri aşağıdaki gibidir:

Belki üniversiteden hocaların okulları ziyaret etmesi bu öğretmenlerle tanışması kaynaşması, özel çocukları anlatması belki daha bir farkındalık uyandırabilir. Çünkü biz ne kadar rehber öğretmen, psikolojik danışman olursak olalım burada her gün görünen bir insan olduğumuz için etkimiz bir yerden sonra azalıyor olabilir. (R3)

Üstün yeteneklilerle psikolojik danışma alanında bilimsel araştırma yapan akademisyen sayısı yok denecek kadar az, kesinlikle çok çalışılması gereken bir alan. Bir kongrede bir iki bildiri vardı bununla ilgili. Onun dışında aklıma gelen çalışma yok. Hani sadece bizim alan için değil tüm alanlar için; fen eğitimi, fizik eğitimi, destek eğitimi, psikolojik danışma konularındaki programlar. Çünkü bunları geliştirme işi biz öğretmenlerin işi değil, uzman gerekiyor. Bu işin girdisi, çıktısı, kazanımı, hedefleri belirlenmeli. Bu konuda akademisyen desteği bekliyoruz. (R8)

Tablo 11. Hâlen Devam Etmekte Oldukları Okullarda Üstün Yetenekli Öğrencilerin Psiko-Sosyal Gelişimlerine Hitap Edilme Durumu

\begin{tabular}{|c|c|c|c|c|c|c|c|c|c|}
\hline $\begin{array}{l}\text { Hâlen Devam } \\
\text { Ettikleri Okullardaki } \\
\text { Program }\end{array}$ & $\begin{array}{l}\text { Nasıl/Nelerin Değişmesi } \\
\text { Gerekiyor }\end{array}$ & R1 & $\mathrm{R} 2$ & R3 & $\mathrm{R} 4$ & R5 & R6 & R7 & $\mathrm{R} 8$ \\
\hline Hitap Ediyor & Farklı etkinlikler uygulanıyor & & & & & $\checkmark$ & & & \\
\hline \multirow[t]{3}{*}{$\begin{array}{l}\text { Kismen Hitap } \\
\text { Ediyor }\end{array}$} & $\begin{array}{l}\text { Farklı bir uygulama yok ama } \\
\text { bunun eksikliğini çok da } \\
\text { hissetmiyorlardır }\end{array}$ & $\checkmark$ & & & & & & & \\
\hline & $\begin{array}{l}\text { Çocuğun bu konuda duyarlı bir } \\
\text { öğretmene rastlamasina bağll }\end{array}$ & & & & & & & $\checkmark$ & \\
\hline & Bireysel görüşmelerle & & $\checkmark$ & & & & & & \\
\hline \multirow[t]{3}{*}{ Hitap Etmiyor } & Tüm eğitimcilere eğitim verilmeli & & & $\checkmark$ & $\checkmark$ & & $\checkmark$ & $\checkmark$ & \\
\hline & Program onlara göre düzenlenmeli & & & & & & $\checkmark$ & & \\
\hline & Akademisyen desteği gerekli & & & $\checkmark$ & & & & & $\checkmark$ \\
\hline
\end{tabular}

\section{Üstün Yetenekliler Programının ve Okuldaki Uygulamaların Üstün Yetenekli Öğrencilerin Eğitim ve Kariyer Olanaklarına Özel Olarak Hitap Etme Durumu}

Bir önceki soruyla benzer şekilde rehber öğretmenlere, özel eğitim ortamlarında ve normal okullarında uygulanan programların üstün yetenekli öğrencilerin eğitim ve kariyer olanaklarına ne ölçüde hitap ettiği sorulmuştur. Öğretmenlerden alınan cevaplar Tablo 12 ve 13 ’te özetlenmiştir. Rehber öğretmenlerin büyük bir kesimi, kısmen de olsa üstün yeteneklilere özgü eğitim veren programların bu öğrencilerin eğitim ve kariyer olanaklarına hitap ettiğini düşünmektedir. Katılımcılardan yalnızca ikisi bu programların tamamen yetersiz olduğunu ve alt yapılarının geliştirilmesi gerektiğini belirtmişlerdir. Buna karşın özel eğitim programlarında öğrencilerin yeteneklerine uygun eğitim imkânlarının sunulduğu fakat kariyer alanında eksikliklerin olduğu göze çarpmaktadır. Bu konudaki öğretmen görüşlerinden bazıları şu şekildedir:

Eğitim olanaklarına hitap ediyor evet. Kariyer olanaklarına, yani şuana kadar ben çocuklarda öyle bir şey görmedim. Yaptıklarını söylüyor ama çocuklar mesela şöyle bir şey yaptık, ben buna ilgi duydum, şunu tercih edeceğim gibi hiçbir şey söylemiyor. (R5)

Zaten bu öğrenciler için en özel yerler bunlar okul dışında BİLSEM'ler okul içerisinde destek eğitim odaları. Yani buralarda bu şekilde hitap edilmesi gerekiyor. BILLSEM'ler 
hakkında pek bilgim yok ama destek eğitim odasında biz biraz daha eğitsel ağıll1klıyız diye düşünüyorum. Ama hiç olmamasından daha iyidir. (R1)

Eğitim alanında muhakkak hitap ediyoruz. Kariyer olanaklarında ise yetenekli olduğu alana yönlendiriliyor. Ama müzikte ve resimde yetenekli olanlarda bazı sıkıntılar var. Çocuk müzikte çok yetenekli olsa bile tıp, mühendislik seçiyor. (R7)

Durumu

Tablo 2. Üstün Yetenekliler Programının Öğrencilerin Eğitim ve Kariyer Olanaklarına Hitap Etme

\begin{tabular}{|c|c|c|c|c|c|c|c|c|c|}
\hline $\begin{array}{l}\text { ÜY Programları } \\
\text { (BİLSEM/Destek } \\
\text { Ĕgitimi ya da BEP) }\end{array}$ & Nasıl/Nelerin Değişmesi Gerekiyor & R1 & $\mathrm{R} 2$ & R3 & R4 & R5 & R6 & R7 & $\mathrm{R} 8$ \\
\hline \multirow[t]{2}{*}{ Hitap Ediyor } & $\begin{array}{l}\text { Yeteneklerine uygun eğitim } \\
\text { imkânları sağlanıyor }\end{array}$ & $\checkmark$ & & $\checkmark$ & & & & $\checkmark$ & \\
\hline & $\begin{array}{l}\text { Farklı etkinlikler düzenleniyor ve } \\
\text { kariyer tercihlerinde yetenekleri } \\
\text { dışındaki değişkenler dikkate } \\
\text { alınıyor }\end{array}$ & & & & & & & $\checkmark$ & $\checkmark$ \\
\hline \multirow{5}{*}{$\begin{array}{l}\text { Kismen Hitap } \\
\text { Ediyor }\end{array}$} & Kariyer alanında eksiklikler var & & & & & $\checkmark$ & & $\checkmark$ & \\
\hline & $\begin{array}{l}\text { Sanatta yetenekli olanlar için özel } \\
\text { eğitim imkânları sağlanıyor }\end{array}$ & & & & & & $\checkmark$ & & \\
\hline & $\begin{array}{l}\text { Kariyer tercihinde çok etkili olan } \\
\text { ailelerin bilinçlendirilmesi gerekli }\end{array}$ & & & & & & & $\checkmark$ & $\checkmark$ \\
\hline & $\begin{array}{l}\text { Sanatta yetenekli olanların kariyer } \\
\text { yönlendirmelerinde eksiklikler var }\end{array}$ & & & & & & & $\checkmark$ & $\checkmark$ \\
\hline & $\begin{array}{l}\text { Alan belirleme konusunda ölçüt } \\
\text { belirlenmeli }\end{array}$ & & & & & & & $\checkmark$ & \\
\hline Hitap Etmiyor & $\begin{array}{l}\text { Alt yap1ları geliştirilmeli (fiziksel } \\
\text { ortam/eğitimci/program) }\end{array}$ & & $\checkmark$ & & $\checkmark$ & & & & \\
\hline
\end{tabular}

Tablo 13'e bakıldığında, öğrencilerin devam ettikleri normal okullarında eğitim ve kariyer olanaklarının özel olarak dikkate alındığını düşünen rehber öğretmen sayısı çoğunluktadır. Hitap ettiği düşünülen okullarda bunun destek eğitim odalarılla (R1), diğer öğrencilere de sunulan standart PDR hizmetleriyle (R2, R3), özel olarak düzenlenen etkinlikler ve bireysel görüşmelerle (R5) sağlandığ1 görülmektedir. Bununla birlikte okullardaki uygulamalarda eksiklikler olduğu ve bazı değişikliklerin yapılması gerektiği bazı katılımcılar tarafindan ifade edilmiştir. Bunlardan en fazla dile getirilen ailelerin eğitimi ve üstün yetenekliliğe bakış açısının değiştirilmesidir. R3 ve R8’in bu konuyla ilgili görüşlerine aşağıda yer verilmiştir:

Diyorum ya önce onlan kabul etmemiz lazım. "Ya onlar şanslı grup" işte "ilgilenilmeye ihtiyacı yok" gibi düşüncelerin değişmesi lazım. Tamam akademik anlamda şanslılar ama bence hayat başarısı olarak bakmamız lazım. Yani arkadaş ilişkileri, evlilik yaşantıları ya da başarılı bir iş bitirebilmek gibi. (R4)

Şey çok önemli bu konuda hani potansiyeliniz var, puanınız var, en iyi denklemi bir araya getirmek önemli. Tercih ederken son noktayı ögrencinin koymasından yanayım. Zaman zaman biz anne babalarıly da konuşuyoruz. Olaya çok fazla müdahil olmamaları konusunda tavsiyede bulunuyoruz. Hani zaten çok iyi puanlara sahip çocuklar. Zaten iyi yerleri hedefliyorlar. (R8)

Tablo 13. Hâlen Devam Etmekte Oldukları Okullarda Üstün Yetenekli Öğrencilerin Eğitim ve Kariyer Olanaklarına Hitap Edilme Durumu

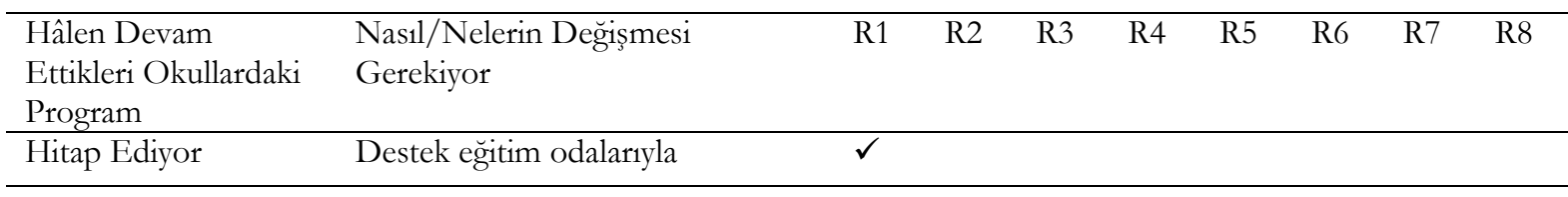


ALTUN, Fatma ve Hikmet YAZICI (2020). “Rehber Öğretmenlerin Üstün Yetenekli Öğrencilere Sunulan Psikolojik Danışma ve Rehberlik Hizmetleri ile İlgili Görüşleri”, Ma vi Atlas, 8(1): 81 -106

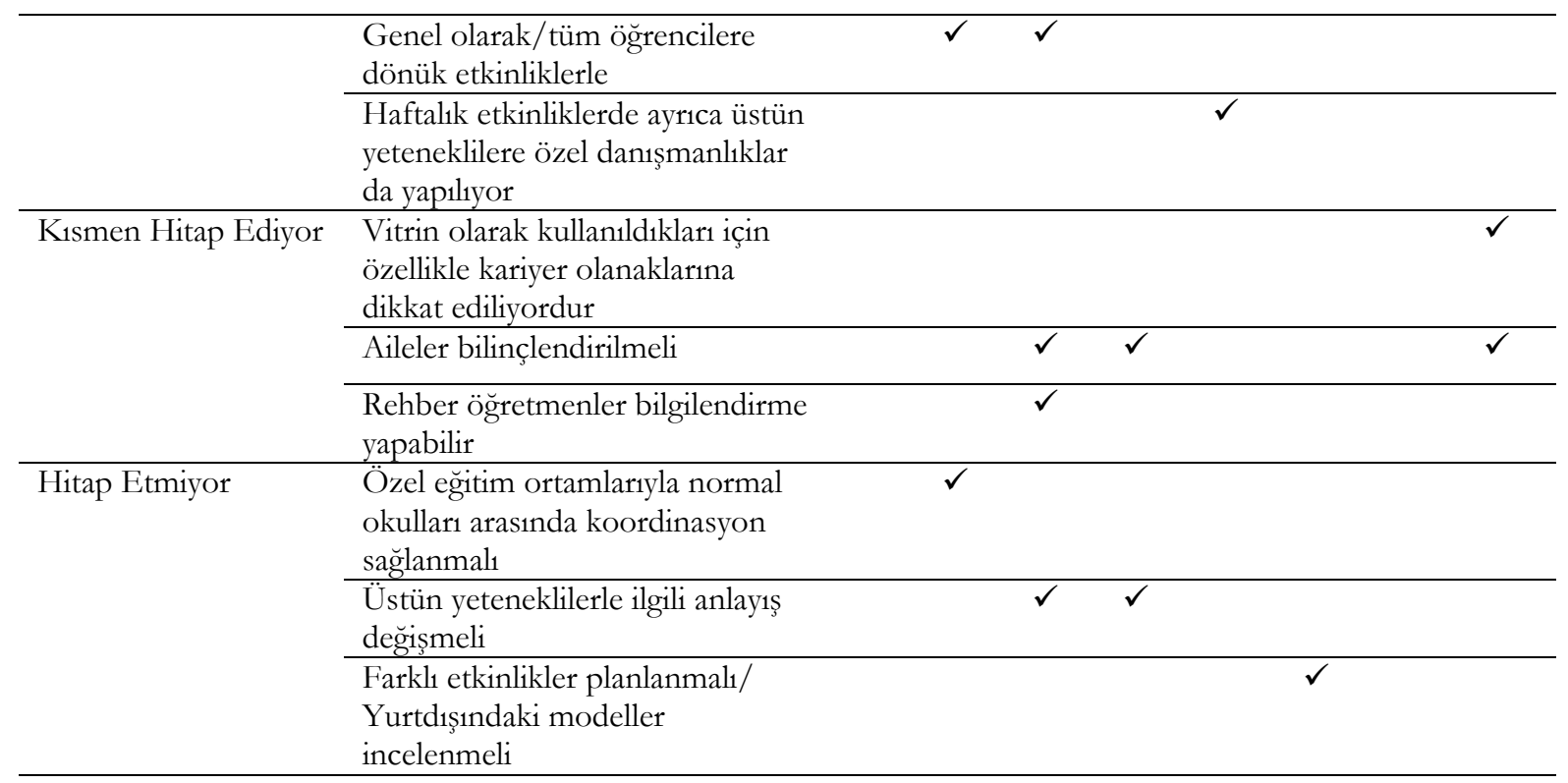

\section{Bölgedeki Üstün Yetenekli Öğrencilerin Eğitimiyle İlgili En Önemli Konu ya da Sorunlara İlişkin Rehber Öğretmenlerin Görüşleri}

Araştırmaya katılan rehber öğretmenlerin bölgedeki üstün yeteneklilerin eğitimiyle ilgili olarak önemli buldukları konu ya da sorunlar Tablo 14'te özetlenmiştir. Buna göre ilk sırda eğitimcilerin üstün yeteneklilerle ilgili yeterli bilgiye sahip olamamaları gelmektedir. Ayrıca bu kategoriyle bağlantılı olarak; öğretmenlerin kendilerini hizmet içinde geliştirmeye firsat bulamadıkları, lisans düzeyinde bu konuyla ilgili ders almadıkları ve özellikle psikolojik danışmanların üstün yeteneklilerle ilgili bilgi eksiklikleri, alandaki önemli sorunlar olarak vurgulanmaktadır. Öğretmenlerin bu konuyla ilgili görüşlerinden bazıları aşağıda sunulmuştur:

Bizim bölgemize has bir durum mudur bilmiyorum ama bence çok fazla bilgi sahibi olmayışımız en büyük sorun. Biz bilgi sahibi değilsek dışarıdaki insan da çok bilgi sahibi değildir diye düşünüyorum. Sadece biz derken psikolojik danışmanları kastetmiyorum eğitim içerisindeki herkesin bilgi sahibi olması gerekir. (R1)

Bilinçsizlik diyebilirim. Bu konuda okul ortamının yeterli bilgisinin ve de donanımının olmaması diyebilirim. Önce eğitim içerisindekilerin farkındalı̆ı̆nın artırılması lazım. (R6)

Kendimin de eğitim aldığım Eğitim Fakültesi de dâhil bu alanda eğitim verilmiyor. Türkiye genelindeki birçok üniversite belki de bu eğitimi vermiyor. Bu eğitimden geçmiş olsa psikolojik danışmanlar bu anlamda daha belirgin farkll1ıklar ortaya koyabilirler. Daha sonra da çok fazla evrak işleriyle boğuştukları için, kendilerini yenileme, geliştirmeye firsat bulamiyorlar. (R2)

Katılımcıların üstün yeteneklilerin eğitimi alanında önemli gördükleri konulardan bir diğeri ise öğrencilerin etiketlenmesi ve buna bağlı olarak öz güven gelişiminin yanlış yönlendirilmesidir. R4, R5 ve R8 bu konuyla ilgili görüşlerini şu şekilde ifade etmektedirler:

Bence öğrencileri tanılayıp egolarını yükseltiyoruz ama yapılan çalışmalar normalleştirme çalışmaları. Tanılamanın da nasıl yapıldığı, hazır bulunuşluğu tartışılır. Çocuk o sorulara cevap vermezse potansiyelini nasil tespit edeceksiniz? Bunun bir kriteri yok. (R4)

Çocuğun kesinlikle duygusal ve alışkanlık eğitimi anlamında gelişimine çok dikkat edilmesi gerekiyor. Yani bu tür çocuklar farklı ama sonuçta bir birey. Bu hayatın içerisinde yaşıyorsa bu hayattaki kurallara, düzene ve yaşama ayak uyduracak bir disiplini kesinlikle alması gerekiyor. Bu olmadan istediğinizi üstüne koymaya çalışın, olmuyor. Bu çocuklar ya şımarık yetişiyorlar, ya aykırı yetişiyorlar. Dolayısıyla da büyüdükleri zaman ön ergenlikleri, ergenlikleri ve daha sonraki süreç çok zor oluyor. (R5) 
ALTUN, Fatma ve Hikmet YAZICI (2020). “Rehber Öğretmenlerin Üstün Yetenekli Öğrencilere Sunulan Psikolojik Danışma ve Rehberlik Hizmetleri ile İlgili Görüşleri”, Ma vi Atlas, 8(1): 81 -106

Bu çocuklar zeki, çalışkan ve yetenekli çocuklar oldukları için okullarda ve dershanelerde vitrin öğrenci olarak kullanılmalarına müsaade etmemek lazım. Yani şöyle düşünün bir anda şöhret oluyorsunuz, tüm spotlar, 1ş1klar yüzünüze tutuluyor. Yani bu yaştaki çocuklar için hiç iyi bir şey değil bu durum. Müthiş bir ilgiyle karşılaşıyorlar. Sınavı atlatıyorsunuz, afişe oluyorsunuz falan, ondan sonra kimse yüzünüze bakmiyor. Yani bu psikolojik olarak çocuğu örseler. Yani bir insan olarak, evet özel yetenekleri olabilir ama hayatının her alanında bu çocuğa hissettirilmemeli, egosu şişiyor çünkü. Bu da iyi bir şey değil. (R8)

Rehber öğretmenlerden bazıları (R7, R8) ise bölgedeki özel eğitim kurumlarındaki fiziksel ve içeriksel eksikliklere dikkat çekmişlerdir. Ayrıca tanılama sürecinde bölgedeki tüm öğrencilere ulaşılamadığ1 (R7) ve özel eğitim gören üstün yetenekli öğrencilerin olumlu örnek oluşturacak, motive edecek şekilde başarılarının gösterilmediği belirtilmektedir (R4).

Tablo 14. Bölgedeki Üstün Yetenekli Öğrencilerin Eğitimiyle ilgili En Önemli Konu/Sorunlara İlişkin Rehber Öğretmenlerin Görüşleri

\begin{tabular}{|c|c|c|c|c|c|c|c|c|}
\hline & R1 & $\mathrm{R} 2$ & R3 & $\mathrm{R} 4$ & R5 & R6 & R7 & R8 \\
\hline Eğitimcilerin bu konuda bilgi sahibi olmayışı & $\checkmark$ & $\checkmark$ & $\checkmark$ & & & $\checkmark$ & $\checkmark$ & \\
\hline $\begin{array}{l}\text { Psikolojik danışmanların bu konuda bilgi sahibi } \\
\text { olmayıș1 }\end{array}$ & & $\checkmark$ & & & & & & \\
\hline $\begin{array}{l}\text { Eğitim fakültelerinde bu konuyla ilgili eğitimin } \\
\text { verilmeyişi }\end{array}$ & & $\checkmark$ & & & & & & \\
\hline $\begin{array}{l}\text { Öğretmenler hizmet içinde kendilerini geliştirmeye } \\
\text { firsat bulamıor }\end{array}$ & & $\checkmark$ & & & & & & \\
\hline Velilerin bilgi yetersizliği & & & $\checkmark$ & & & & & \\
\hline $\begin{array}{l}\text { Üstün yeteneklilere dönük programların başarılı } \\
\text { sonuçlarının görülmeyişi }\end{array}$ & & & & $\checkmark$ & & & & \\
\hline $\begin{array}{l}\text { Sadece etiketlemenin yapılması/özgüven gelişiminin } \\
\text { yanlış yönlendirilmesi }\end{array}$ & & & & $\checkmark$ & $\checkmark$ & & & $\checkmark$ \\
\hline $\begin{array}{l}\text { Öğrencilerin farklı alanlarını geliştirebilecekleri } \\
\text { kurum çeşitliliğinin olmayışı }\end{array}$ & & & & & $\checkmark$ & & & \\
\hline Tanilamayla ilgili sorunlar & & & & $\checkmark$ & & & $\checkmark$ & \\
\hline $\begin{array}{l}\text { Özel eğitim kurumlarının fiziksel ve program } \\
\text { içeriklerinin yetersizlikleri }\end{array}$ & & & & & & & $\checkmark$ & $\checkmark$ \\
\hline
\end{tabular}

\section{Rehber Öğretmenlerin Üstün Yetenekli Öğrencilere Özgü Bir Rehberlik Programının Geliştirilmesine Yönelik Önerileri}

Görüşmenin son sorusu olarak, üstün yeteneklilere özgü bir rehberlik programının geliştirilmesiyle ilgili rehber öğretmenlerin önerilerinin neler olduğu sorulmuştur. Katılımcıların cevapları Tablo 15 'te gösterilmiştir. Öğretmenlerin büyük bir kısmı programda yer alması gereken etkinlikler hakkında önerilerde bulunurken bazıları programın genel yapısıyla (Program yeni başlayanlar için yol gösterici olmalı ve ihtiyaca göre esnetilebilmeli), bazıları ise rehber öğretmenlerin çalışma şartlarıyla (Bir rehber öğretmene 25 öğrenci düşmeli) ilgili görüşlerini dile getirmişlerdir. Rehber öğretmenlerin daha çok birleştikleri nokta üstün yetenekli öğrencilerin eğitsel anlamda çok fazla sıkıntı yaşamadıkları o yüzden programda sosyal-duygusal yönlerine ağırlık verilmesidir. Örneğin R4, R6 ve R7 bu konudaki görüşlerini şu şekilde ifade etmektedirler:

Onların ruhsal gelişimleri açısından, sosyal gelişimleri açısından daha etkili olmasını sağlayıcı bir program hazırlanmalı. Zaten bilişsel alanda çok büyük bir şeye ihtiyaçları yok. Alıp götürüyorlar. Duygusal anlamda, etik anlamda, kişilik anlamında iyi bir şekilde gelişmelerine önem verilmeli. (R7)

Sosyal yönlerinin gelişmesi için, duygusal sorunlarının giderilmesine ve iletişim becerilerinin gelişmesine yönelik çalışmalar eklenebilir programa. Gelişmesine derken hani iletişim becerileri zaten var ama zorluk çekiyorlar bazı konularda. Bu nedenle programda daha çok sosyal alana ağırlık verilebilir. (R6) 
Sadece akademik olarak eğitmiyoruz ki biz bu çocukları. Zaten eksik oldukları alan akademik değil. Ama elimizde bunlarla ilgili bir kaynak yok. Onların yetenek ve zekâ seviyelerine göre onların hazır bulunuşluğuna uygun etkinlikler bilimsel olarak araştırllmış mı? Bir kere onların yaşadıkları sorunların boyutlandırılması gerekmiyor mu? Akademik anlamda, eğitim, mesleki, iletişim anlamında hangi sıkıntıları yaşıyorlar ve bu konularda hangi etkinlikler faydalı, bunların programa eklenmesi gerekiyor. Çünkü programdaki mevcut etkinlikler öğrencilere saçma geliyor, yapmak istemiyorlar. (R4)

Üstün yeteneklilere özgü bir programda yer almasının gerekli görüldüğü başlıklardan bir diğeri ise üstün yetenekliliğin hem öğrencilere hem velilere tanıtılmasıdır. Bunun yanı sıra öğrencilerle ve velilerle yapılacak görüşmelerin sıklı̆̆ının artırılması da bazı katılımcılar tarafından vurgulanmıştır. Rehber öğretmenlerden bazıları ise grup çalışmalarına ağırlık verilmesinin faydalı olduğunu ayrıca uygulanacak etkinliklerin içeriklerinin bilimsel olarak kanıtlanmış olmasına dikkat edilmesi gerektiğini ifade etmişlerdir.

Tablo 15. Üstün Yetenekli Öğrencilere Özgü Bir Rehberlik Programının Geliştirilmesine Dönük Öneriler

\begin{tabular}{|c|c|c|c|c|c|c|c|c|}
\hline & R1 & $\mathrm{R} 2$ & R3 & R4 & R5 & R6 & R7 & $\mathrm{R} 8$ \\
\hline $\begin{array}{l}\text { Öğrencilerin yetenek ve yaratıcılıklarını sergileyebilecekleri } \\
\text { aktiviteler içermeli }\end{array}$ & $\checkmark$ & & & & & $\checkmark$ & & \\
\hline Belli periyotlarla bireysel görüşmeler olmalı & & $\checkmark$ & & & & & & \\
\hline Sportif ve sosyal faaliyetler olmalı & & $\checkmark$ & & & & & & \\
\hline Bir rehber öğretmene 25 öğrenci düşmeli & & $\checkmark$ & & & & & & \\
\hline Veli görüşmelerine daha sık yer verilmeli & & & $\checkmark$ & & $\checkmark$ & & & \\
\hline $\begin{array}{l}\text { Grup çalışmaları (Karar verme becerileri, mükemmeliyetçilik ve } \\
\text { kariyer yönlendirmeleri konusunda) yapılmalı }\end{array}$ & $\checkmark$ & & & $\checkmark$ & & & & \\
\hline $\begin{array}{l}\text { Bilimsel olarak üstün yeteneklilere hitap ettiği kanıtlanmış } \\
\text { etkinlikler olmalı }\end{array}$ & & & $\checkmark$ & $\checkmark$ & & & & \\
\hline Üstün yetenekliliği (öğrencilere ve velilere) tanıtmalı & & & & $\checkmark$ & $\checkmark$ & & $\checkmark$ & \\
\hline Öğrencilerin sosyal-duygusal yönüne ağırlık verilmeli & & & & $\checkmark$ & $\checkmark$ & $\checkmark$ & $\checkmark$ & \\
\hline Toplumsal duyarlılı̆̆ artırıc1 etkinlikler içermeli & & & & & & & $\checkmark$ & \\
\hline $\begin{array}{l}\text { Program yeni başlayanlar için yol gösterici olmalı ve ihtiyaca göre } \\
\text { esnetilebilmeli }\end{array}$ & & & $\sqrt{ }$ & & & & & $\checkmark$ \\
\hline
\end{tabular}

\section{Tartışma ve Sonuç}

Bu araştırma kapsamında, özel yeteneklilere sunulan PDR hizmetlerinin değerlendirilmesi amacıyla rehber öğretmenlerle yarı yapılandırılmış görüşmeler gerçekleştirilmiştir. Görüşmelerden elde edilen sonuçlara göre rehber öğretmenlerin çoğu üstün yeteneklilere dönük özel bir eğitim almamıştır. Bununla birlikte hizmet içi eğitim sürecinde aldıkları eğitimin sadece tanılama amacıyla kullanılan testlerin uygulanmasıyla ilgili olduğu ve üstün yetenekli öğrencilerin özellikleri, PDR ihtiyaçlarıyla ilgi herhangi bir bilginin verilmediği tespit edilmiştir. Üstün yetenekli öğrencilere eğitim veren diğer branş öğretmenleri ile yapılan çalışmaların (Altun ve Vural, 2012; Satmaz ve Evin-Gencel, 2016) sonucunda da hizmet içi eğitimdeki yetersizliklere dikkat çekildiği görülmektedir. Ayrıca bu çalışmadaki rehber öğretmenlerin lisans düzeyinde aldıkları eğitimin özel eğitim dersi içerisinde sadece bir bölüm olması, rehber öğretmenlerin görüşlerine göre yetersiz bulunmuştur. Yazıcı ve Altun (2016) tarafindan yapılan çalışmada da bu yetersizliğe dikkat çekildiği görülmektedir. BİLSEM'de çalışan rehber öğretmenlerin ise katıldıkları çalıştay ve seminerlerde daha çok üstün yeteneklilerin genel özellikleri ve öğretim stratejileri üzerinde durulduğu görülmektedir.

Görüşmelerden elde edilen bir diğer bulguya göre üstün yetenekli öğrencilerin en temel ihtiyaçlarının ilk sırasında farklılıklarının anlaşılması ve saygı duyulması gelmektedir. Ayrıca kendi özelliklerine uygun eğitim kurumları ve farklılaştırılmış programlara gereksinim duydukları 
belirtilmiştir. Bu görüşler liteatürde üstün yeteneklilerle ilgili sılklıkla vurgulanan (Colangelo ve Assouline, 2000; Davis ve Rimm, 2004; Silverman, 1993a) temel konularla tutarlık göstermektedir.

Görüşmeye katılan rehber öğretmenlerin üstün yeteneklilerin PDR ihtiyaçlarıyla ilgili görüşleri daha çok kişisel-sosyal ve eğitsel alanda yoğunlaşmaktadır. Bu görüşlere göre öğrencilerin eğitsel alanda yaşadıklanı sorunlar; sınıfta sıkılma, okula gitme konusunda isteksizlik, sınav kaygısı ve motivasyonsuzluktur. Kişisel sosyal alanda ise akran ilişkilerindeki sorunlar, mükemmeliyetçilik ve üstün yeteneklilik etiketinin olumsuz etkileri gibi konuların yer aldığı belirlenmiştir. Rehber öğretmenlerin bu tespitleri Altun ve Yazıcı (2018b) tarafindan yapılan çalışmadaki üstün yetenekli öğrencilerin belirttikleri sorunlarla paralellik göstermektedir. Bu çalışmadaki üstün yetenekli ögrrencilerin de kendilerini en çok rahatsız eden konular arasında; okulu terk etme isteği, mükemmeliyetçilik, diğerleri tarafından farklı algılanma, üstün yeteneklilik etiketi ve buna dönük beklentilerle başa çıma gibi endişelerin yer aldığ1 bulunmuştur. $\mathrm{Bu}$ sorunlar, daha önceki araştırmalarda da (Berlin, 2009; Parker ve Adkins, 1995; Wood, 2009; Yoo ve Moon, 2006) üstün yetenekli öğrencilerin sıklıkla karşılaştıkları ve PDR hizmetlerine gereksinim duydukları problemler arasında gösterilmektedir. Bu araştırmadaki yarı yapılandırılmış görüşmelerde rehber öğretmenlerin üstün yeteneklilerin mesleki rehberlik ihtiyaçlarına pek değinmedikleri görülmektedir. Oysaki literatürde (Altun ve Yazıc1, 2018b; Kerr, 1991; Silverman, 1993b) üstün yetenekli öğrencilerin çok yönlü potansiyele sahip oldukları ve kendilerine uygun bir kariyer planını oluşturmakta zorlandıkları yönünde bulgular mevcuttur. Araştırmamızdaki rehber öğretmenlerin özel yetenekli öğrencilerin mesleki rehberlik ihtiyaçlarına vurgu yapmaması bu öğrencilerin oldukça yüksek sınav ve okul puanlarına sahip olmaları ve bir üst öğrenim kurumuna yerleşmekte zorluk çekmemeleri ile ilgili olabilir. Türkiye'deki mesleki rehberlik çalısmaları için bu yeterli bir hizmet olarak görülmektedir. Literatürde önerilen; okul öncesinden başlayan bir kariyer eğitimi ve çok yönlü değerlendirme yaklaşımlarını içeren mesleğe yönlendirme sisteminin ülkemizde uygulandığını söylemek oldukça zordur.

Rehber öğretmenlerin üstün yetenekli öğrencilerin ihtiyaçlarını belirlerken çoğunlukla öğretmen görüşlerinden yararlandıkları sonucuna ulaşılmıştır. Bunun yanı sıra kendi gözlemleri, velilerinin ve diğer öğrencilerin beyanlarından da yararlandıkları tespit edilmiştir. Bu durum üstün yeteneklilerle danışma yaparken birçok kaynaktan bilgi edinilmesi yönündeki yaklaşımlarla (Kerr, 1991; Moon ve Hall, 1998) tutarlıdır. Buna karşı rehber öğretmenlerden çok azı üstün yetenekli öğrencilerin karşılaştı̆̆1 sorunlarla ilgili rehberlik servisine başvurduklarını belirtmektedirler. Üstün yetenekli öğrencilerin PDR servislerinden yardım almaya dönük bu davranışları, daha önceki araştırma sonuçları (Altun, 2010; Altun ve Yazıc1, 2018b; Peterson ve Ray, 2006) da dikkate alındığında beklenen bir durumdur. Bununla birlikte rehber öğretmenlerden çok azının üstün yetenekli öğrencilerin ihtiyaçlarının belirlenmesinde yapılandırılmış formlardan ya da standart ölçme araçlarından yararlandığı tespit edilmiştir. Oysaki bu tür formların doğru bir şekilde kullanılması ile öğrencilerin problem alanları kolaylıkla tespit edilebilir ya da rehberlik servisine yansımayan bazı PDR ihtiyaçları ortaya çıkarılabilir. Fakat araştırmamızdaki rehber öğretmenlerin bu tür formları kullanmayışı, üstün yeteneklilerin PDR ihtiyaçlarının belirlenmesine dönük ölçme araçlarının sinırlılığından da kaynaklanabilir.

Araştırmaya katılan rehber öğretmenlerin bazıları üstün yetenekli öğrencilere dönük aktivitelerle ilgili bilgi sahibi olmadığını ve standart PDR hizmetlerini uyguladıklarını belirtmişlerdir. Buna karşın öğretmenlerin çoğu üstün yetenekli öğrencilerin PDR ihtiyaçlarının karşılanması için özel yöntemler uygulanması gerektiğinin farkındadırlar. Bunun için rehber öğretmenlerin en çok kullandıkları ve faydalı olduğunu düşündükleri yöntemler bireysel görüşmeler, öğretmen bilgilendirmeleri ve veli görüşmeleridir. Fakat rehber öğretmenlerin bu görüşmelerde üstün yetenekliler için geliştirilen yaklaşım ve stratejileri kullanmadıkları belirlenmiştir. Araştırmamızdaki rehber öğretmenler daha çok üstün yetenekliler hakkında sahip oldukları bilgi ve deneyimleriyle standart PDR hizmetlerini birleştirme yoluna gitmektedirler. Bu bağlamda üstün yeteneklilerle 
çalışırken, grup rehberliği, akran danışmanlığı, drama çalışmaları ve yeteneklerini sergileyebilecekleri etkinlerde bu öğrencilere sorumluluk verme gibi uygulamaları başarılı bulmaktadırlar. Yapılan bu uygulamalar literatürde üstün yetenekli öğrenciler için önerilen stratejiler arasında yer almaktadır (Colangelo, 2003; Silverman, 1993c). Buna karşın literatürde üstün yetenekliler için önerilen; bibliyoterapi, aileler ile psikolojik danışma ve rehberlik uygulamaları ve farklılaştırılmış bireysel danışma uygulamaları gibi pek çok stratejinin olduğu unutulmamalıdır. Ayrıca burada bahsedilen yöntemlerin sadece birkaç rehber öğretmen tarafından kullanıldığına da dikkat çekmek gerekir.

Üstün yeteneklilere dönük PDR hizmetlerinde rehber öğretmenlerin, sıradan/ezberci etkinlikleri kullanışsız buldukları ve bazen aile desteğinin ve bireysel görüşmelerdeki devamlılı̆̆ının sağlanması hususunda başarısız oldukları belirlenmiştir. Bunun yanı sıra empatik olmayan ve alandaki uzmanlığını hissettirmeyen rehber öğretmen tutumlarının da başarısız sonuçlar verdiği belirtilmektedir. Rehber öğretmenlerin kendi deneyimleriyle ulaştıkları bu sonuçlar üstün yeteneklilerle çalışanlar için oldukça önemli ipuçları taşımaktadır. Zira üstün yeteneklilere dönük kullanılan stratejilerin hangilerinin kullanışsız olduğunun bilinmesi de önemli bir çıkış noktasıdır. Ayrıca rehber ögrretmen standartlarının ve rollerinin belirlenmesinde bu gibi durumların dikkate alınması oldukça önemli görülmektedir. Bu kapsamda, uzun y1llar tartışlan "Üstün yetenekli öğrencilerin öğretmenleri de üstün yetenekli olmalı mıdır?” konusunun artık psikolojik danışmanlarını da kapsaması söz konusu olabilir. Fakat bu soruya cevap verebilmemize yardımcı olacak bir araştırma bulgusuna henüz rastlanılmamıştır. Bununla birlikte öğretmenler için yapılan tartsşmalarda ulaşılan sonuç (Sak, 2011) ve üstün yetenekli öğrencilerin görüşleri (Vialle ve Quigley, 2003; Vialle ve Tischler, 2005) dikkate alındığında bizim çalışmamızdaki rehber öğretmenlerin belirttiği özellikler ön plana çıkmaktadır. Buna göre, üstün yetenekli öğrencilerle çalışan rehber öğretmenler alanlarında uzman ve üstün yeteneklilerin bilişsel ve duygusal ihtiyaçlarına hitap edebilecek yeterlikte olmalıdır.

Araştırmamızdaki rehber öğretmenlerin tümü eğitimcilerin ve okul psikolojik danışmanlarının üstün yetenekliler konusunda yeterli bilgiye sahip olmadığı görüşündedirler. Üstelik bu durumu üstün yeteneklilerin eğitimiyle ilgili en önemli sorun olarak değerlendirmektedirler. Rehber öğretmenlerin bu yetersizliklerin giderilmesine ilişkin önerileri ise üstün yeteneklilerle ilgili lisansta ayrı bir dersin olması ve belirli periyotlarla hizmet içi eğitimlerin düzenlenmesidir. Rehber öğretmenlerden bazıları ise tanılama araçlarıyla ve mesleki etikle ilgili eğitimlere ağırlık verilmesinden bahsetmişlerdir. Üstün yetenekli öğrencilerin doğru ve adil bir tanılama sisteminden geçmeleri, uygun eğitim programlarına yönlendirilmeleri ve özgün özelliklerine duyarlı psikolojik danışma hizmetleri alabilmeleri için okul rehber öğretmenlerinin bu alandaki yeterlik düzeylerinin artırılması gerektiği literatürde sıkça vurgulanan konular arasındadır (ASCA, 2013; Gentry, 2006; Silverman, 1993c). Bizim çalışmamızda rehber öğretmenlerin de bu konudaki eksikliklerinin farkında oldukları ve profesyonel gelişimleri adına bu alanda eğitime ihtiyaç duydukları ortaya konulmuştur.

Görüşmelere katılan rehber öğretmenlerden bazıları mevcut rehberlik programını üstün yeteneklilere dönük uygulamalar bakımından yeterli görürken çoğu bu programının pek çok eksik yönünün olduğunu vurgulamışır. Katılımcıların çoğu uygulanan rehberlik programının daha çok öğrencilerin eğitim ve kariyer olanaklarına hitap ettiği, psiko-sosyal ihtiyaçlarının ise ikinci planda kaldığ1 yönünde görüş bildirmişlerdir. Buna dayalı olarak rehber öğretmenlerden geliştirilecek bir program için önerileri istenmiştir. Öğretmenlerden bazıları üstün yetenekliliği doğru bir şekilde tanıtan ve öğrencilerin yeteneklerini sergileyebilmelerine olanak sunan etkinliklere yer verilmesi gerektiğini belirtmişlerdir. Rehber öğretmenlerden bazıları ise bu alandaki pek çok araştırmacının (Robinson, Shore ve Enersen, 2014; Wood, 2010) vurguladığ1 gibi üstün yetenekli öğrencilere özel olarak geliştirilmiş ve etkililiği bilimsel olarak kanıtlanmış etkinliklerin programda yer alması gerektiğini ifade etmişlerdir. Rehber öğretmenlerin daha çok birleştikleri nokta; üstün yetenekli öğrencilerin eğitsel anlamda çok fazla sıkıntı yaşamadıkları o yüzden programda sosyal-duygusal 
yönlerine ağırlık verilmesidir. Oysaki üstün yetenekli öğrencilerin okullarda karşılaştıkları pek çok sorun yeteneklerine ve ilgilerine uygun eğitim ortamlarının sağlanmamasından kaynaklanmaktadır (Kerr, 1991; Moon, Kelly ve Feldhusen, 1997; Siegle ve McCoach, 2005). Türkiye'de üstün yeteneklilerin ebeveynleri ile yapılan çalışmada (Altun ve Yazıc1, 2018a) bu çalışmadakine benzer şekilde üstün yetenekli çocuklarının en fazla sorun yaşadıkları konuların eğitim planlamaları ve okul ile ilgili olduğu ortaya konulmuştur. Fakat araştırmamızdaki rehber öğretmenlerin de belirttiği gibi öğrencilerin sosyal-duygusal gelişimleri de göz ardı edilemez. Bunun için son yıllarda üstün yetenekli öğrencilere özel eğitim verilen kurumlarda psiko-sosyal gelişimlerinin de dahil edildiği müfredatlar uygulanmaktadır (Rachmel, 2007). Benzer şekilde üstün yeteneklilere özgü bir rehberlik programının da tüm boyutları dengeli bir şekilde içermesi daha uygun olabilir.

Sonuç olarak, rehber öğretmenlerle yarı yapılandırılmış görüşmelerden elde edilen bulguların çoğu daha önceki araştırmaların sonuçlarıyla tutarlılık göstermektedir. Bununla birlikte bu görüşmeler sayesinde rehber öğretmenlerin üstü/özel yetenekli öğrencilerle ilgili PDR hizmetleri ile ilgili görüşlerine açıklı getirildi. Yine bu bölümde tartışlan bulguların, üstün/özel yetenekli öğrencilere dönük PDR hizmetlerindeki eksikliklerin nedenlerinin anlaşılması ve bunların giderilmesine yönelik çözüm önerileri getirilmesi açısından önemli olduğu düşünülmektedir. Bu bulgulara dayanılarak okul ve BİLSEM rehberlik programlarının üstün yetenekli öğrencilerin ihtiyaçlarına göre düzenlenmesi önerilmektedir. Ayrıca üstün yetenekli öğrencilere hizmet verecek rehber öğretmenlerin hizmet öncesi ve hizmet içerisinde farklılaştırılmış PDR uygulamaları ile ilgili eğitimlere alınması önerilebilir. Ayrıca bu çalışmanın sınırlılıkları göz önünde alındığında yapılacak araştırmalara yönelik de bazı önerilerde bulunulabilir. Örneğin bu çalışmada yalnızca rehber öğretmenlerle görüşmeler yapılmıştır. Rehberlik hizmetlerinde etkili olan diğer tarafların (aile, öğretmen, yönetici) ve öğrencilerin kendileri ile de derinlemesine görüşmelerin yer aldığ1 nitel çalışmalar tasarlanabilir. Bu sayede hem kültüre özgü durumların hem de konuyla ilgili anlaşmazlık ve uyum gösterilen noktaların keşfedilmesine olanak sağlanmış olacaktır.

\section{Kaynakça}

ALTUN, Fatma (2010). Üstün Yetenekli Öğrencilerin Mükemmeliyetçilik Özellikleri, Okul Motivasyonları, Öğrenme Stilleri ve Akademik Başarıları, (Yayınlanmamış Yüksek Lisans Tezi), Sosyal Bilimler Enstitüsü, Karadeniz Teknik Üniversitesi, Trabzon.

ALTUN, Taner ve Selma VURAL (2012). "Bilim ve Sanat Merkezinde (BİLSEM) Görev Yapan Öğretmen ve Yöneticilerin Mesleki Gelişim ve Okul Gelişimine Yönelik Görüşlerinin Değerlendirilmesi”, Elektronik Sosyal Bilimler Dergisi, 11(42): 152-177.

ALTUN, Fatma ve Hikmet YAZICI (2014). "Perfectionism, School Motivation, Learning Styles and Academic Achievement of Gifted and Non-Gifted Students", Croatian Journal of Education: Hrvatski časopis za odgoj i obrazovanje, 16(4): 1031-1065.

ALTUN, Fatma ve Hikmet YAZICI (2018a). “Türkiye'deki Üstün Yetenekli Öğrencilerin Psikolojik Danışma ve Rehberlik İhtiyaçları”, Ankara Üniversitesi Eğitim Bilimleri Fakültesi Örel Eğitim Dergisi, 19: 1-24.

ALTUN, Fatma ve Hikmet YAZICI (2018b). "Üstün Yetenekli Öğrencilerin Psikolojik Danışma Yaşantıları: Ölçek Uyarlama ve Kesitsel Tarama Çalışması”, Milli Ë̆itim Dergisi, 47 (Özel Say1 1): 173-200.

American School Counselor Association (ASCA) (2013). "Position Statement: The Professional School Counselor and Gifted and Talented Student Programs". Alexandria, VA: (https://www.schoolcounselor.org/asca/media/asca/PositionStatements/PositionStatements.pd f).

BAHTIYAR, Muhammed ve Feyzullah ŞAHIN (2017). "Üstün Yetenekli Öğrencilerin Rehberlik Gereksinimi”, Journal of Educational Studies, 4(2): 140-154. 
ALTUN, Fatma ve Hikmet YAZICI (2020). “Rehber Öğretmenlerin Üstün Yetenekli Öğrencilere Sunulan Psikolojik Danışma ve Rehberlik Hizmetleri ile İlgili Görüşleri”, Ma vi Atlas, 8(1): 81 -106

BAŞLANTI, Uğur \& D. Betsy McCOACH (2006). "Factors Related to the Underachievement of University Students in Turkey", Roeper Review, 28(4): 210-215.

BERLIN, Judith Ellen (2009). "It's All a Matter of Perspective: Student Perceptions on The Impact of Being Labeled Gifted and Talented", Rooper Review, 31(4): 217-223.

COLANGELO, Nicholas (2003). "Counseling Gifted Students", eds. N. Colangelo \& G. A. Davis, Handbook of Gifted Education, 3rd ed., pp. 373-387, Boston: Allyn and Bacon.

COLANGELO, Nicholas \& Susan G. ASSOULINE (2000). "Counseling Gifted Students”, eds. K. A. Heler, F. J. Mönks, R.J. Sternberg, \& R. F. Subotnik, International Handbook of Giftedness and Talent, 2nd ed., pp. 595-607, Oxford: Elsevier.

COLANGELO, Nicholas, \& Gary A. DAVIS (2003). "Introduction and Overview", eds. N. Colangelo \& G. A. Davis, Handbook of Gifted Education, 3rd ed., pp. 7-8, Boston: Allyn and Bacon.

ÇAĞLAR, Doğan (2004). "Üstün Zekâlı Çocukların Eğitimi ve Öğretimi”, haz. M. R. Şirin vd. Üstün Yetenekli Cocuklar: Seçilmiş Makaleler Kitabı, ss. 265-274, İstanbul: Çocuk Vakfı Yayınları.

DAVIS, Gary, \& Sylvia RIMM (2004). Education of the Gifted and Talented, 5th ed., Boston: Pearson Education.

DENSCOMBE, Martyn (2007). The Good Research Guide for Small-Scale Social Research Projects, 3rd ed., Berkshire: Open University Press.

GALL, Meredith Damien; GALL, Joyce P. \& Walter R. BROG (2003). Educational Research: An Introduction, 7th ed., Boston: Allyn and Bacon.

GENTRY, Marcia (2006). "No Child Left Behind: Gifted Children and School Counselors", Professional School Counseling, 10(1): 73-81.

HANSEN, Rayn (2009). "Terman's Studies of Genius”, ed. B. Kerr, Encyclopedia of Giftedness, Creativity and Talent, pp.890-892, California: Sage Publications.

HOLLINGWORTH, Leta S. (1942). Children Above 180 IQ Stanford-Binet: Origin and Development. Measurement and Adjustment Series, pp. 174-185, Yonkers-on-Hudson, NY, US: World Book Company.

JOHNSEN, Susan K. (2004). "Definitions, Characteristics of Gifted Students”, ed. S. K. Johnsen, Identifying Gifted Students: A Practical Guide, pp. 1-24, Texas: Prufrock Press.

KERR, Barbara (1991). A Handbook For Counseling the Gifted and Talented. Alexandria, VA: American Counseling Association.

KERR, Barbara \& Sandro SODANO (2003). "Career Assessment with Intellectually Gifted Students”, Journal of Career Assessment, 11(2): 168-186.

KOÇAK, Recep ve Eda İÇMENOĞLU (2012). "Üstün Yetenekli Öğrencilerin Duygusal Zekâ Ve Yaratıcılık Düzeylerinin Yaşam Doyumlarını Yordayıcı Rolü”, Türk Psikolojik Damıs̆ma ve Rebberlik Dergisi, 4(37): 73-85.

LINCOLN, Yvonna S. \& Egon G. GUBA (1985). Naturalistic Inquiry. London: Sage.

MILES, Matthew B. \& A. Michael HUBERMAN (1994). Qualitative Data Analysis, 2nd ed., London: Sage.

MILGRAM, Roberta A. (1991a). "Career Education For Gifted Learners", ed., R. A. Milgram, Counseling Gifted and Talented Children: A Guide For Teachers, Counselors, and Parents, pp.121138, Norwood, New Jersey: Ablex Publishing Corporation.

MILGRAM, Roberta A. (1991b). "Counseling Gifted and Talented Children and Youth: Who, Where, What and How?", ed., R. A. Milgram, Counseling Gifted and Talented Children: A Guide For Teachers, Counselors, and Parents, pp.7-21, Norwood, New Jersey: Ablex Publishing Corporation. 
MILLİ EĞİTIM BAKANLIĞI (2018). Psikolojik Danışma ve Rehberlik Hizmetleri Yönetmeliği. T.C. Resmi Gazete, 30471, Tebliğler Dergisi, Temmuz 2018/20180707.

MOON, Sidney M. (2002a). "Counseling Needs and Strategies", eds. M. Neihart, S. M. Reis, N. M. Robinson and S. M. Moon, The Social and Emotional Development of Gifted Children: What Do We Know?, pp.213-222, Washington, DC: Prufrock Press.

MOON, Sidney M. (2002b). Gifted Children with Attention-Dificit/Hyperactivity Disorder", eds., M. Neihart, S. M. Reis, N. M. Robinson, \& S. M. Moon, The Social and Emotional Development of Gifted Children: What Do We Know?, pp.193-201, Washington, DC: Prufrock Press.

MOON, Sidney M. (2007). "Counseling Issues and Research", ed. S. Mendaglio \& J. S. Peterson, Models of Counseling Gifted Children, Adolescents, and Young Adults, pp.7-32, Waco, TX: Prufrock Press Inc.

MOON, Sidney M. \& Alex S. HALL (1998). "Family Therapy with Intellectually and Creatively Gifted Children", Journal of Marital and Family Therapy, 24: 59-80.

MOON, Sidney M., KELLY, Kevin R., \& John F. FELDHUSEN (1997). "Specialized Counseling Services for Gifted Youth and Their Families: A Needs Assessment", Gifted Child Quarterly, 41(1): 16-25.

NEIHART, Maureen (1999). "The Impact of Giftedness on Psychological Well-Being: What Does the Empirical Literature Say?", Rooper Review, 22: 10-12.

ÖZDEMIR, Duygu (2018). "Matematikte Üstün Yetenekli İlköğretim Öğrencilerinin Okullarındaki Matematik Derslerine İlişkin Algıları", Kastamonu Ĕ̈itim Dergisi, 26(1): 153-160.

PARKER, Wayne D., \& Karen K. ADKINS (1995). "Perfectionism and the Gifted", Roeper Review, 17(3): 173-175.

PETERSON, Jean Sunde \& Karen E. RAY (2006). "Bullying Among the Gifted: The Subjective Experience”, Gifted Child Quarterly, 50(3): 252-269.

PIECHOWSKI, Michael M. (2009). "The Iner World of The Young and Bright”, eds., D. Ambrose \& T. Cross, Morality, Ethics, and Gifted Minds, pp. 177-194, New York: Springer Science+Business Media.

RACHMER, Shlomit (2007). "The New Policy for Promoting Education for Outstanding and Gifted Students in Israel", eds., P. Csermely et al., Science Education: Models and Networking of Student Research Training Under 21, pp.130-140, Balatonfüred, Hungary: IOS Press.

RENZULLI, Joseph S., \& Sunghee PARK (2002). Giftedness and High School Dropouts: A Personal, Family, and School-Related Factors. Washington, DC: National Research Center on the Gifted and Talented.

ROBSON, Colin (1993). Real World Research. Oxford: Blackwell Publishers Ltd.

ROBINSON, Ann, DAILEY, Debbie, HUGHES, Gail \& Alicia COTABISH (2014). "The Effects of A Science-Focused STEM Intervention on Gifted Elementary Students' Science Knowledge and Skills", Journal of Advanced Academics, 25(3): 189-213.

SATMAZ, İsmail ve İlke EVIN-GENCEL (2016). "Bilim Sanat Merkezlerinde Görevlendirilen Öğretmenlerin Hizmet İçi Eğitim Sorunu”, Doku₹ Eylül Üniversitesi Buca Eğitim Fakültesi Dergisi, (42): 59-73.

SCHIEVER, Shirley W. \& Carol June MAKER (2003). New Directions in Enrichment and Acceleration, eds., N. Colangelo \& G. A. Davis, Handbook of Gifted Education, 3rd ed., pp.163-173, Boston, MA: Allyn and Bacon.

SEELEY, Ken (1993). "Gifted Students at Risk", ed., L. K. Silverman, Counseling the Gifted and Talented, pp. 263-275, Denver, Colorado: Love Publishing Company. 
ALTUN, Fatma ve Hikmet YAZICI (2020). “Rehber Öğretmenlerin Üstün Yetenekli Öğrencilere Sunulan Psikolojik Danışma ve Rehberlik Hizmetleri ile İlgili Görüşleri”, Ma vi Atlas, 8(1): 81 -106

SHENTON, Andrew K. (2004). "Strategies For Ensuring Thrustworthiness in Qualitative Research Projects", Education for Information, 22: 63-75.

SIEGLE, Del, \& Betsy McCOACH (2005). "Making A Difference: Motivating Gifted Students Who Are Not Achieving", Teaching Exceptional Children, 38(1): 22-27.

SILVERMAN, Linda Kreger (1993a). "The Gifted Individual”. ed., L. K. Silverman, Counseling The Gifted and Talented, pp. 3-28, Denver, Colorado: Love Publishing Company.

SILVERMAN, Linda Kreger (1993b). "Career Counseling”, ed., L. K. Silverman, Counseling the Gifted and Talented, pp. 215-238, Denver, Colorado: Love Publishing Company.

SILVERMAN, Linda Kreger (1993c). "A Developmental Model for Counseling the Gifted”, ed., L. K. Silverman, Counseling the Gifted and Talented, pp. 51-78, Denver, Colorado: Love Publishing Company.

STRICKLAND, Bonnie R. (2001). Gale Encyclopedia of Psychology, 2nd ed., Ohio: Eastword Publication Development.

VANTASSEL-BASKA, Joyce (1990). "Introduction”, Ed., J. VanTassel-Baska, A Practical Guide to Counseling the Gifted in a School Setting, 2nd ed. pp. 9-13,. Reston, Virginia: ERIC Clearinghouse on Handicapped and Gifted Children.

VANTASSEL-BASKA, Joyce., \& Ariel BASKA (2019). Curriculum Planning and Instructional Design for Gifted Learners. Sourcebooks, Inc.

VIALLE, Wilma \& Siobhan QUIGLEY (2003). “The Teachers We Want: Exploring The Views Of Gifted Students", eds., F. J. Mönks \& H. Wagner, Proceedings of The 8th Conference of The European Council for High Ability (ECHA): Development of Human Potential: Investment Into Our Future ,pp. 125-128, Bad Honnef, Germany: K. H. Bock.

VIALLE, Wilma, \& Kornelia TISCHLER (2005). "Teachers of the Gifted: A Comparison of Students' Perpectives in Australia, Austria and The United States", Gifted Education International, 19(2): 173-181.

WEBB, James T. (1994). Nurturing Social-Emotional Development of Gifted Children, Arlington, VA: The ERIC Clearinghouse.

WOOD, Susannah (2009). "Counseling Concerns of Gifted and Talented Adolescents: Implications for School Counselors", Journal of School Counseling, 7(1): 1-47.

WOOD, Susannah (2010). "Best Practices in Counseling the Gifted in Schools: What's Really Happening?”, Gifted Child Quarterly, 54(1): 42-58.

YAZICI, Hikmet \& Fatma ALTUN (2016). "PDR Lisans Programlarının Üstün Yeteneklilere Dönük Psikolojik Danışma Becerilerinin Kazandırılması Açısından Değerlendirilmesi”, HAYEF Journal of Education, 13(1): 61-72.

YILDIRIM, Ali ve Hasan ȘIMȘEK (2008), Sosyal Bilimlerde Nitel Araștrma Yöntemleri, 7. Bask1, Ankara: Seçkin Yayıncılık.

YOO, Jin Eun \& Sidney M. MOON (2006). "Counseling Needs of Gifted Students: an Analysis of Intake Forms At A University- Based Counseling Center", Gifted Child Quarterly, 50(1): $52-61$. 
ALTUN, Fatma ve Hikmet YAZICI (2020). "Rehber Öğretmenlerin Üstün Yetenekli Öğrencilere Sunulan Psikolojik Danışma ve Rehberlik Hizmetleri ile İlgili Görüşleri”, Mavi Atlas, 8(1): 81 -106

Ek

Etik Kurul İzni

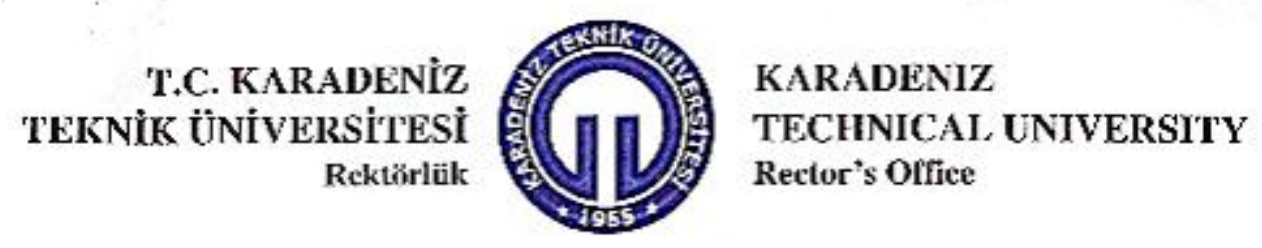

Hukuk Mūşavirliği
Sayı/Ref
$82554930 / 1100-1578$
$12 / 12 / 2014$
Konu/Subj. :

Sn. Dos. Dr. Hikmet YAZICI

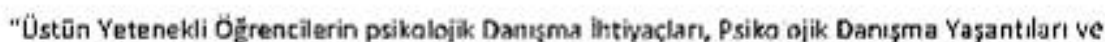
Sehber Ogretınenlerin Üstun Yeteneklilerle iggili Yeterlik Düceyleri" adlı TüBiTaK proje Snęrisi için gerekli alan Etik Kurul incelemesi yapilmuş ve onay verilmiştir.

Bilgilerinizi rica ederim.

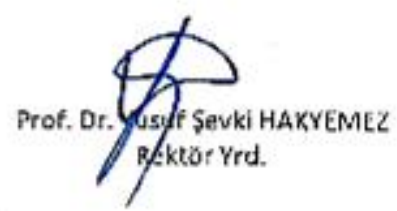

GLQRo-Tralyon: i TORKTYE

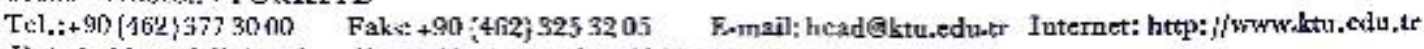
Hukuk Miigs:sirịğ Tel. : $(0462) 372107-(0462) 3253241$ 